\title{
Assessing the Social, Cultural, Economic and Environmental Conditions of Nambale Town in Busia County, Kenya
}

\author{
Okusimba George Omusotsi ${ }^{1}$,, Alima Tovesi Dennis ${ }^{2}$, Cheboi John Kilimo², Machoka Alex ${ }^{2}$, \\ Kurgat Kevin Kipchirchir ${ }^{2}$, Jepchirchir Cynthia ${ }^{2}$, Lagat Mercy², Ngoko Wycliffe Oloo², \\ Kisera Fredrick Ogutu ${ }^{2}$ \\ ${ }^{1}$ Department of Civil \& Structural Engineering, University of Eldoret, Eldoret, Kenya \\ ${ }^{2}$ Department of Environmental Monitoring, Planning and Management, University of Eldoret, Eldoret, Kenya
}

Email address:

gokusimba@gmail.com (O. G. Omusotsi)

${ }^{*}$ Corresponding author

\section{To cite this article:}

Okusimba George Omusotsi, Alima Tovesi Dennis, Cheboi John Kilimo, Machoka Alex, Kurgat Kevin Kipchirchir, Jepchirchir Cynthia, Lagat Mercy, Ngoko Wycliffe Oloo, Kisera Fredrick Ogutu. Assessing the Social, Cultural, Economic and Environmental Conditions of Nambale Town in Busia County, Kenya. Urban and Regional Planning. Vol. 4, No. 1, 2019, pp. 16-38. doi: 10.11648/j.urp.20190401.13

Received: March 4, 2019; Accepted: April 29, 2019; Published: May 7, 2019

\begin{abstract}
The preparation of an Integrated Urban Development Plan (IUDP) for an urban center requires a grasp of the situation in terms of issues and challenges facing the residents of that particular urban center. The strengths, weaknesses, opportunities and threats can then be analyzed and the planning process approached in an integrated manner. The integration is not only in terms of sectors, but also the stakeholders including the public and urban management. Nambale town is a vibrant urban establishment along the Mumias-Busia highway and one of the towns within Busia County, Kenya. This study sought to carry out a situation analysis of Nambale town with a view of bringing out issues that will inform the preparation of an IUDP. Data from different sectors (Education, Housing, Economic sector, Health, Recreation, Transport, Energy, Environment, Water and Security) was collected, analyzed and presented. Questionnaires, key informant interviews and consultative meetings were some of the methods that were used to collect the data. The data gathered and information generated will hopefully assist in the preparation of an IUDP and result in a sustainable and resilient urban Nambale.
\end{abstract}

Keywords: Nambale, Social, Cultural, Economic, Environmental Conditions

\section{Introduction}

The world we live in has transformed and continues to change, this transformation having an impact on urban areas. Today, cities are home to fifty four percent of the world's population, and by the middle of this century that figure will rise to sixty six percent [1]. This growth has been accelerated by three major factors, that is, natural increase among urban residents, reclassification of formerly rural areas as urban and internal rural-urban migration [2]. As a result, there has been increasing demand for key services which among others include provision of shelter, water and sanitation, education, health, infrastructure and employment.

As much as urbanization brings effectiveness and efficiency in various aspects of economic, social, political, technological and legal scales, it has also brought with it multi-dimensional challenges which include inadequate social services, lack of proper housing, congestion, inadequate water and sanitation services, increased crime rates, lack of socio-economic diversity, poor road network, urban heat island effect, poor solid waste management, unemployment, pollution and lack of adequate green spaces [3].

Many urban centers in most developing countries, Kenya included, are not up to task in dealing with multi-dimensional challenges that come along with urbanization. In order to 
develop mitigation and adaptation strategies to the above problems, integrated spatial urban planning is vital. Integrated urban planning is a modern planning approach closely connected with the complex nature of the cities and necessity of creating sustainable and resilient settlements. Research has shown that the implementation of integrated urban planning is directly connected to the socio-economic conditions, legal frameworks, technology, and professional and educational potentials of societies, which differ for each country [4].

The Kenyan Government for instance has made it mandatory for all urban areas to have an integrated development plan to guide its developments alongside being used to give it a status (whether it is a market center, a town, a municipal or a city). It has also put in place requisite institutional framework to guide in spatial planning in the country including Urban Areas and Cities Act 2011 amended 2015 [5], Physical Planning Act 286 of 1996 [6] and County Governments Act of 2012 [7], among other institutions.

Strategic planning is an extended tool for regional and urban development and can be defined as a systematic form of preparing for change and for the future of a city. Strategic planning takes into account the socio-economic and environmental context. Nowadays, the analysis of potentials, limitations, opportunities and threats is a critical part of the strategic management planning process (Khalifipour et al., in [8]). The development of an IUDP therefore requires initial understanding of the situation in the area in terms of social, economic, cultural and environmental conditions. Nambale is a small vibrant town along the Mumias-Busia road facing a number of challenges brought about by rapid growth and lack of an integrated urban plan to guide development. Assessing the socio-economic, cultural and environmental conditions of this town is critical to the development of a plan that will serve the town for the next few decades.

\section{Methodology}

\subsection{Description of Study Area}

The study was carried out in Nambale sub-county, Busia County in Kenya. The area is located between latitudes $0^{\circ} 36$ '52" and $0^{\circ} 234^{\prime \prime} "$ and longitudes $34^{\circ} 12^{\prime} 44^{\prime \prime}$ and $34^{\circ} 24^{\prime} 33^{\prime \prime}$ ' and has an average altitude of 3900 feet above the sea level. Nambale sub-county is one of the seven subcounties in Busia County. Administratively, the sub-county is divided into four wards, namely: Nambale Township, Bukhayo North/Walatsi, Bukhayo East and Bukhayo Central [9].

The size of Nambale sub-county is $237.8 \mathrm{Km}^{2}$ with a projected population of 105,686 by 2030 . The settlement patterns are dictated by economic factors, access to social amenities, infrastructure and security. Nambale town has a higher population mainly because of the opportunities of trading and availability of other social amenities. The population trend indicates a high population growth rate of about 3.9 percent per annum.

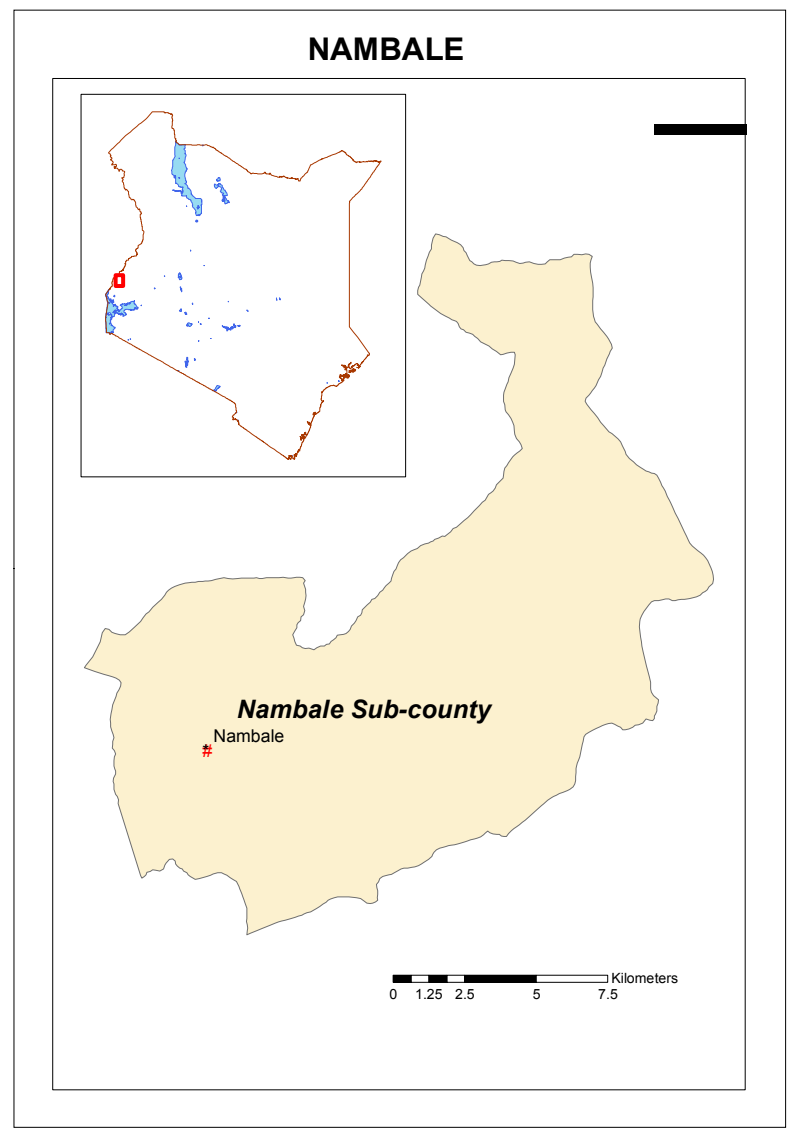

Figure 1. Nambale subcounty (Data source: Independent Electoral \& Boundaries Commission [IEBC]).

Although most parts of Busia County have sandy loam soils, Nambale sub-county which is in the lower northern part has dark clay soils. This land formation and structure makes it suitable for both food and cash crops farming like tobacco, cotton, maize, robusta coffee and sugar cane. The county is also served by rivers Malakisi to the extreme North and river Sio in Funyula and Nambale sub-counties. The Sio river water supply serves Busia town and its environs and the people of Nambale sub-county.

The temperatures for the whole county are homogeneous. The annual mean maximum temperatures range between $26^{\circ}$ celcius and $30^{\circ}$ celcius while the mean minimum temperature range between $14^{\circ}$ celcius and $22^{\circ} \mathrm{Celsius}$.

Nambale sub-county is characterized by three topographical features namely; river valleys and plains, the wetlands and springs. River Sio is the main stream feeding into river Nzoia which drains into Lake Victoria.

\subsection{Data Acquisition}

Transect Survey: With line transect sampling, the basic idea is that an observer moves along a line through a study area, looking to the left and right for occurrences of interest. Line transects are walked, flown, or otherwise traversed, and the perpendicular distances to all detected items of interest are recorded. Combining these data with the assumption that all items on the line are detected, it is possible to correct the 
estimates of abundance per unit area for the items not detected. When an individual of the species of interest is detected, it is recorded, usually together with its distance from the line, because it is assumed that individuals that are far from the line are harder to detect than those that are close [10]. This method was used to assist in having an overview of Nambale town in terms of issues related to urban planning. Nambale town has two major transects: Butula-Amukura and Busia-Mumias road. During this study, the junction was picked as the starting point, resulting in four transects. Nambale town towards Mumias transect covered a stretch of approximately $4.1 \mathrm{~km}$ from Nambale town in the West-East direction. It is a tarmac road with the following features along it: Commercial activities on both sides of the road within the first few meters from the junction. They include mainly shops and hotels among others. On the northern side of the transect, the following are the major features: Bus park, medical center, power lines, filling station, a wetland which included a river, water treatment plant, telecommunication mast, forest, storm water drainage, urban agriculture, early childhood development center, Kisoko Primary School, Kisoko Boys High School, St. Ann's Kisoko Girls High School and finally Kisoko shopping center. In between, especially after the wetland, there exist residential homes. The main housing typology is semi-permanent houses and row housing. On the southern side of the transect, the following were the major features: church, resort, sugarcane plantation, wetland with a stream and a swamp, Mumias sugar company sugarcane collection center, brick making points, storm water drainages and power lines.

Nambale town towards Busia transect covers a distance of approximately $4 \mathrm{~km}$ from Nambale town in the east-west direction. The road is tarmacked and serves as the main route to Busia town, the county headquarters for Busia County. Commercial activities are dominant on both sides, milk processing plant, police station, sugarcane collection point, cooperative bank, river, wetland, urban agriculture, filling station, car wash, Nambale Magnet School, churches, offices (Assistant Chief, Constituency Development Fund and Land Surveyor), sub county hospital, sterling medical center and St. Mary's primary school. However development along this transects depicts leap frog model.

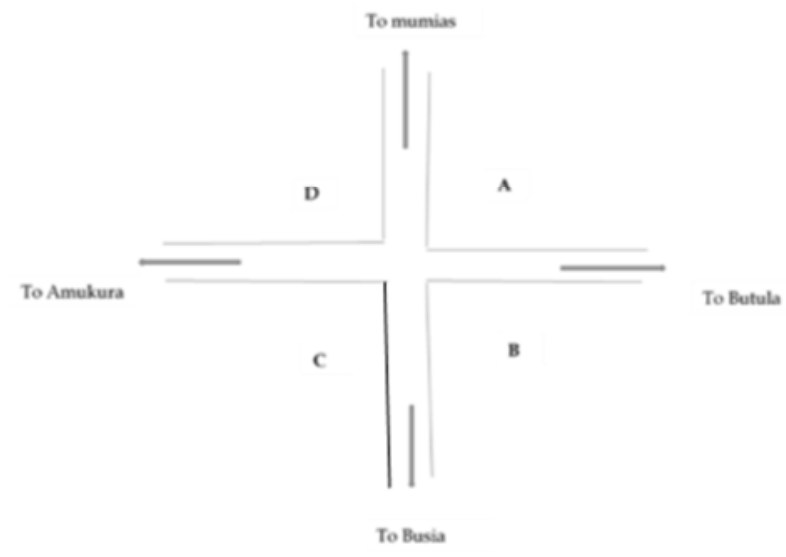

Figure 2. Main transects in Nambale.
Nambale town toward Amukura transect covers a distance of $2.4 \mathrm{~km}$ from Nambale town in North-South direction. The road is not tarmacked, it is an earth surfaced road. Commercial activities are dominating within the Central Business District. Other activities along this transect include: Nambale Urban Primary, both semipermanent and permanent bungalows, high rise commercial developments, churches, power line, telecommunication mast, hotel, transformer, private tree plantations, sugarcane plantations, urban agriculture, coffee nursery and brick making points.

Nambale town towards Butula transect covers a distance of approximately $3 \mathrm{~km}$ from Nambale town in South-North direction. Commercial activities are dominant here. The road is not tarmacked. Other features include Member of County Assembly's office, recreational centers, light industry, police divisional headquarters, Nambale Preparatory school, private forests, river, Coffee Farmers' Cooperative and storm water drainage.

A number of key issues arose out of the transect survey. Unplanned solid waste disposal points, leapfrog developments along the road, inadequate boda- boda parking areas and narrow roads. There also existed encroachment on road reserve, unprotected environmentally sensitive areas and inadequate market space.

Key Informant Interviews and Key Stakeholder Consultative Meetings: Focused interviews were carried out with questions designed to unearth answers pertinent to the project. The first meeting was at the office of Land, Physical Planning, Housing \& Urban Development at the Busia County headquarters where the interview with key informants preceded on the basis of an interview guide specifying topics related to the project. Later on a comprehensive and effective interaction with the sectoral heads took place. The sectoral offices that were visited were the agriculture sector; public service; education, youth affairs, gender \& social services; health and sanitation; land, physical planning, housing \& urban development; public works, energy, roads and transport; tourism, culture, arts \& sports; enterprise, ICT and industrial development; and water, irrigation, environment and natural resources.

The purpose of visiting these sectoral offices was to seek for: significant gaps in the county establishment; key areas of concern to the departments; key challenges they encounter; how the challenges can be addressed; proposed programmes; key flagship projects in different departments; and how departments plan to undertake development control.

A one-day consultative meeting was held at Nambale sub-county headquarter with stakeholders to discuss and get an in-depth understanding of the conditions of Nambale town and how they envisioned the town to be in future.

Questionnaires: The questionnaire was structured into eleven sections including- the general information, social sector, education sector, health sector, recreation, security, infrastructure, energy, water, waste management, 
environment and economic. They were pre-tested before they were administered to check their effectiveness in capturing the required data. Simple random sampling was used to select the respondents because it was easy to use and provided more accurate representation of the information needed.

\section{Results and Analysis}

\subsection{Analysis of Respondents}

Majority of the respondents interviewed were females $(64 \%)$ while male respondents were $(39 \%)$. This could imply that during the day, more men are out there working compared to women whose main role in this particular region is to perform household chores. The figures below further illustrates gender and age distribution of the respondents during the field study. The target population were adults hence as evident from the pyramid, the age distribution starts at around age twenty from the y-axis.

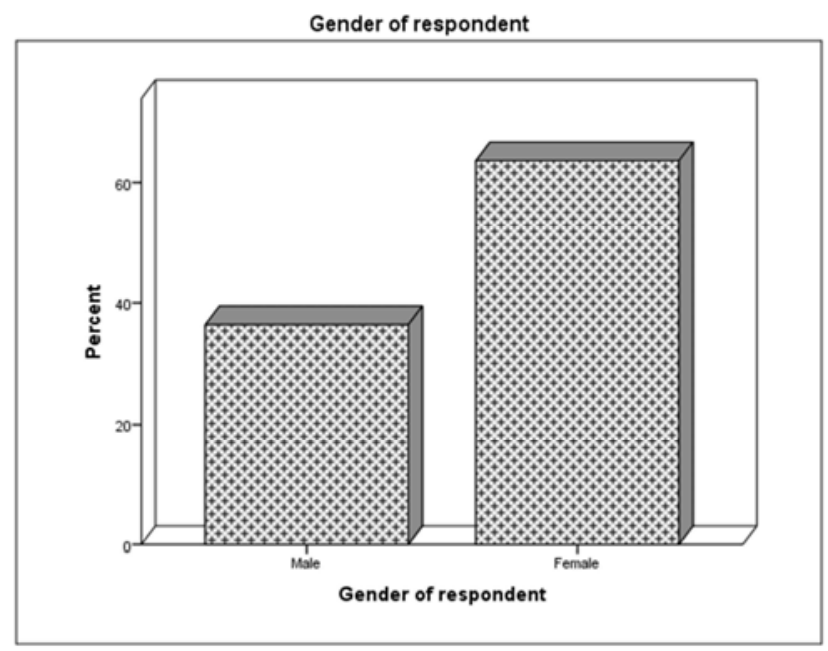

Figure 3. Respondents by gender.

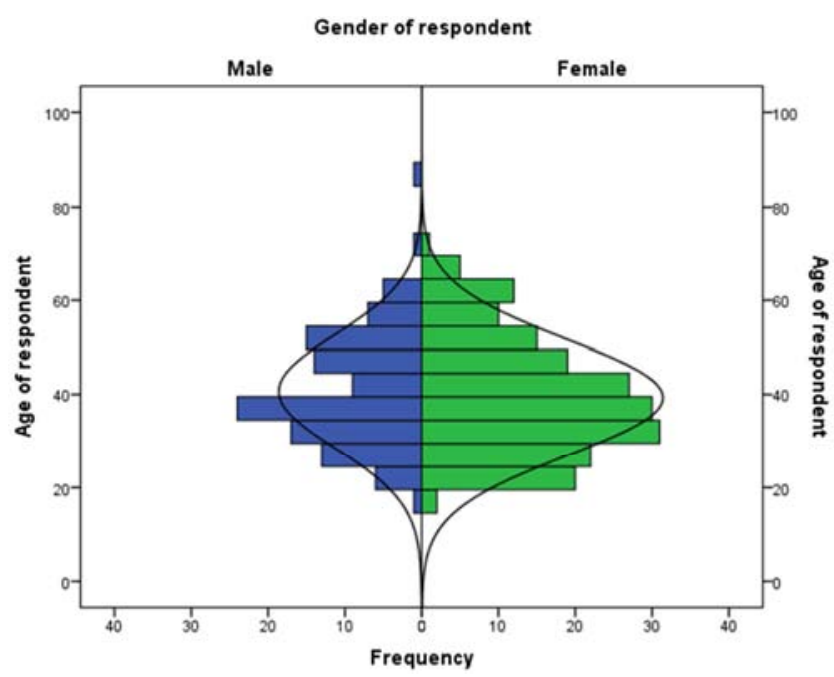

Figure 4. Respondent by age.

Field results revealed that majority of the population in
Nambale town were married (79\%) while $12 \%$ of population were single with $5 \%$ percent being widowed, $2 \%$ separated and $2 \%$ of the respondents were divorced. Figure 5 below presents the distribution of respondents by marital status.

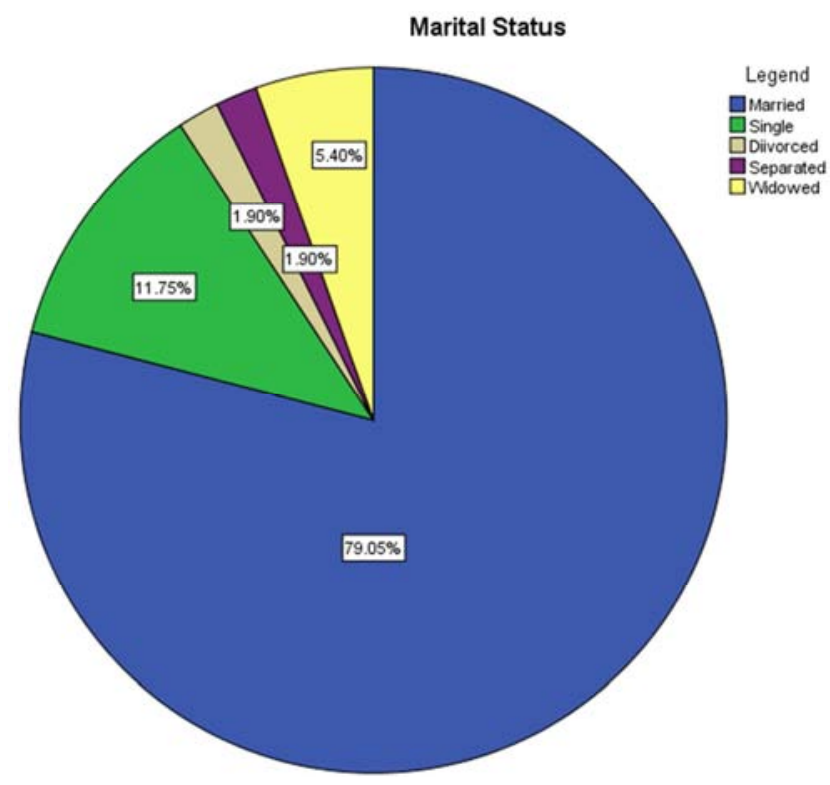

Figure 5. Marital status of respondents.

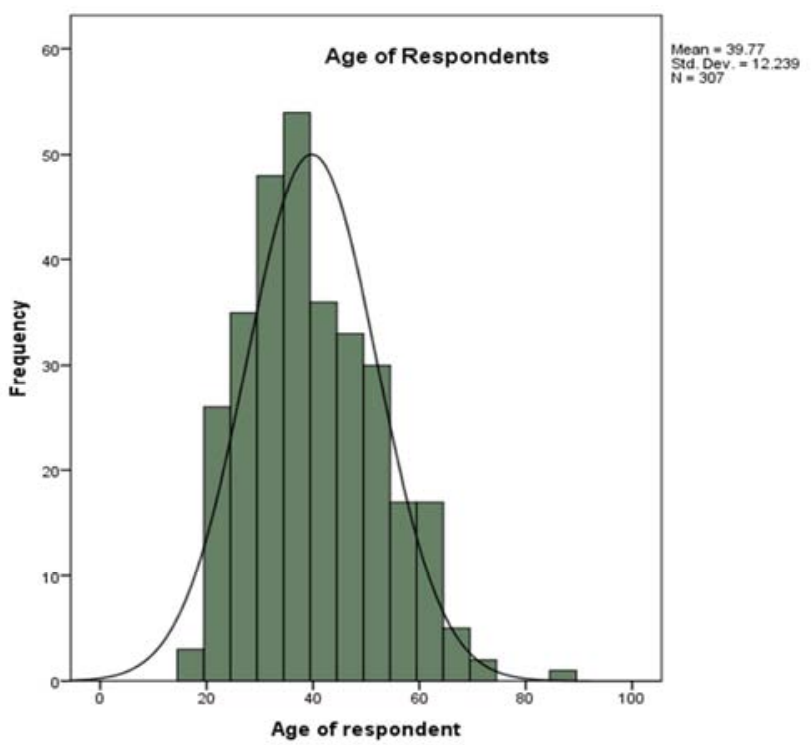

Figure 6. Age of respondents.

According to the field survey, majority of the respondents were aged forty years (figure 6). This implies that a large population is the working age hence very productive economically.

As illustrated in figure 7 below, majority of the respondents had some level of education whether primary, secondary or tertiary. A higher number of people interviewed had completed both primary and secondary schools compared to those who never attended school at all. This is advantage to the residents of Nambale because of the fact that an educated society is destined to prosper. 


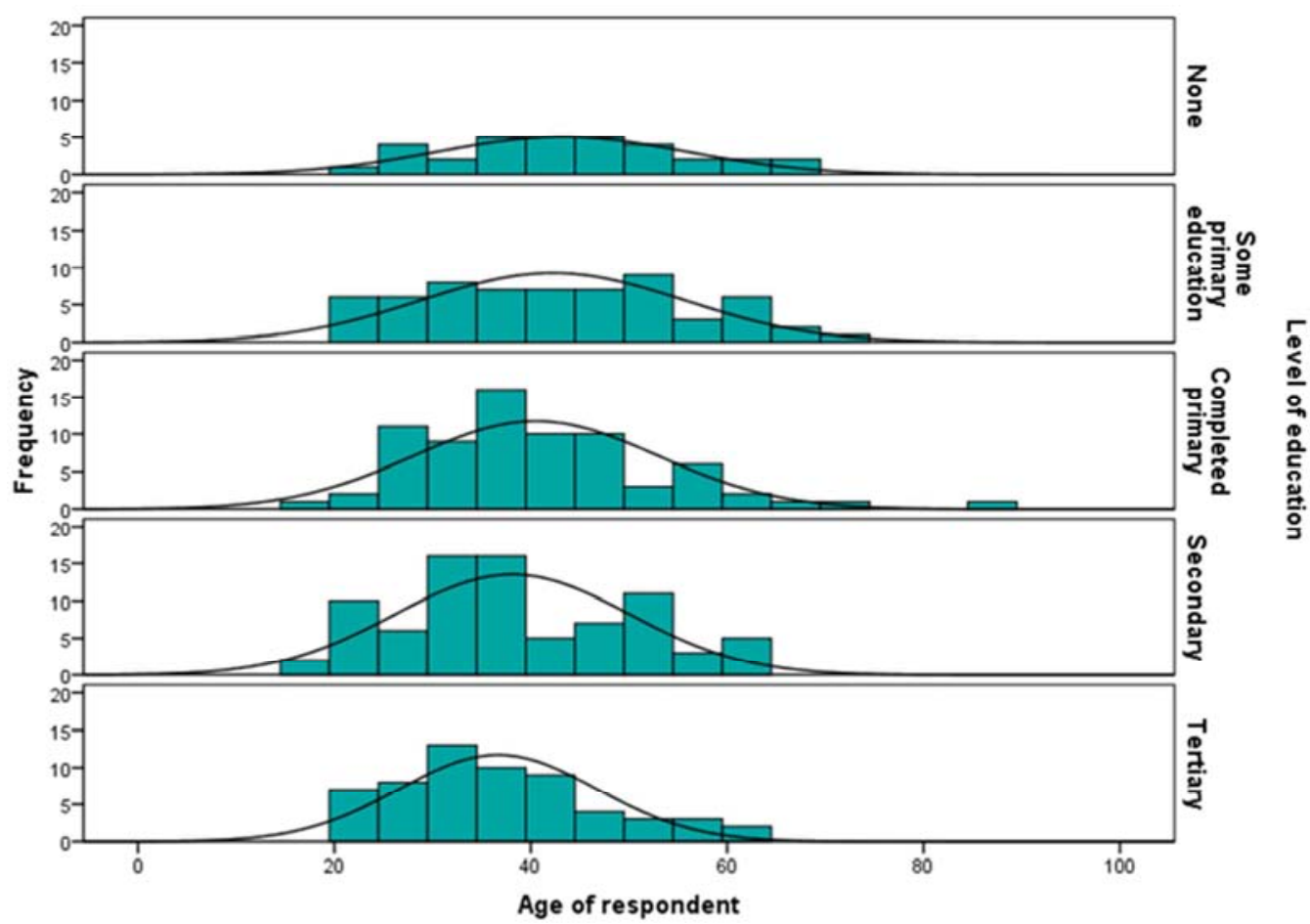

Figure 7. Education level of respondents.

\section{Occupation of Nambale Residents}

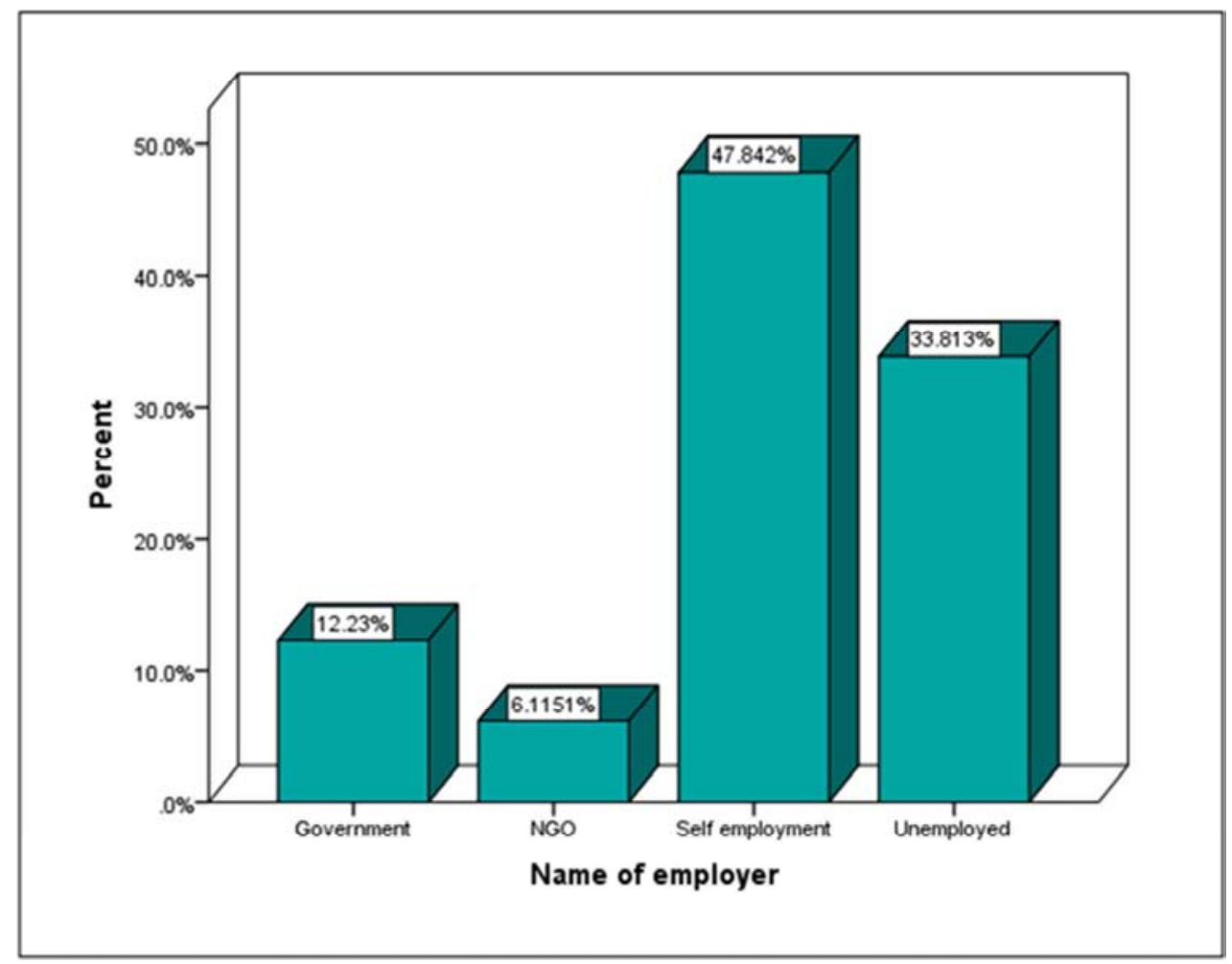

Figure 8. Occupation of respondents.

According to the data collected and analyzed, a larger number of the residents are self-employed followed by those unemployed then followed by those employed by government and finally those employed by NGO's. In general, a large number of the populace in Nambale are unemployed $(65 \%)$ as compared to the employed (35\%). This has a negative implication to the growth of the economy of the area because of high dependency ratio. 


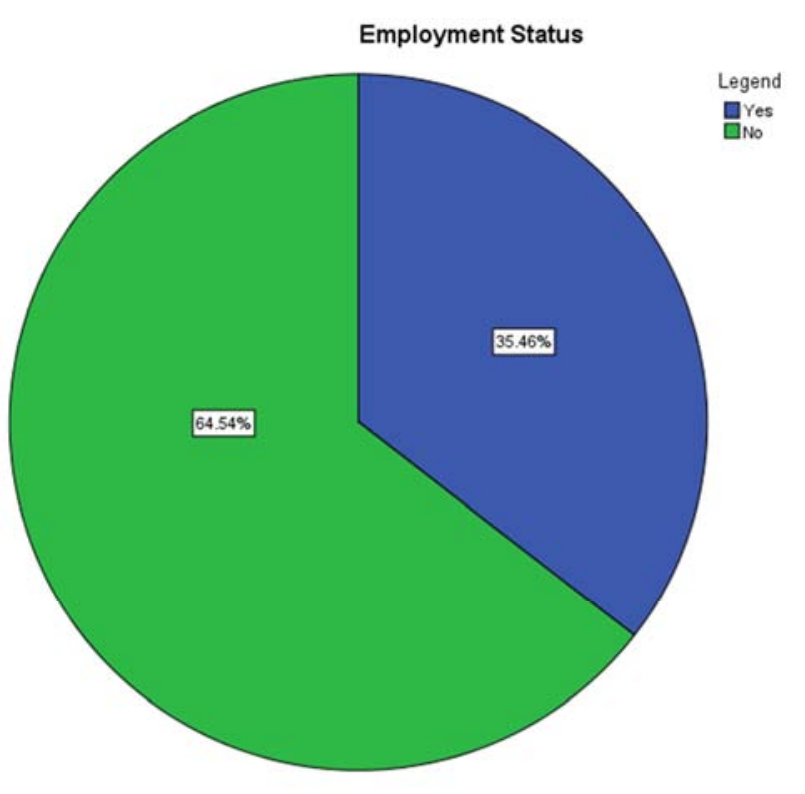

Figure 9. Employment status.

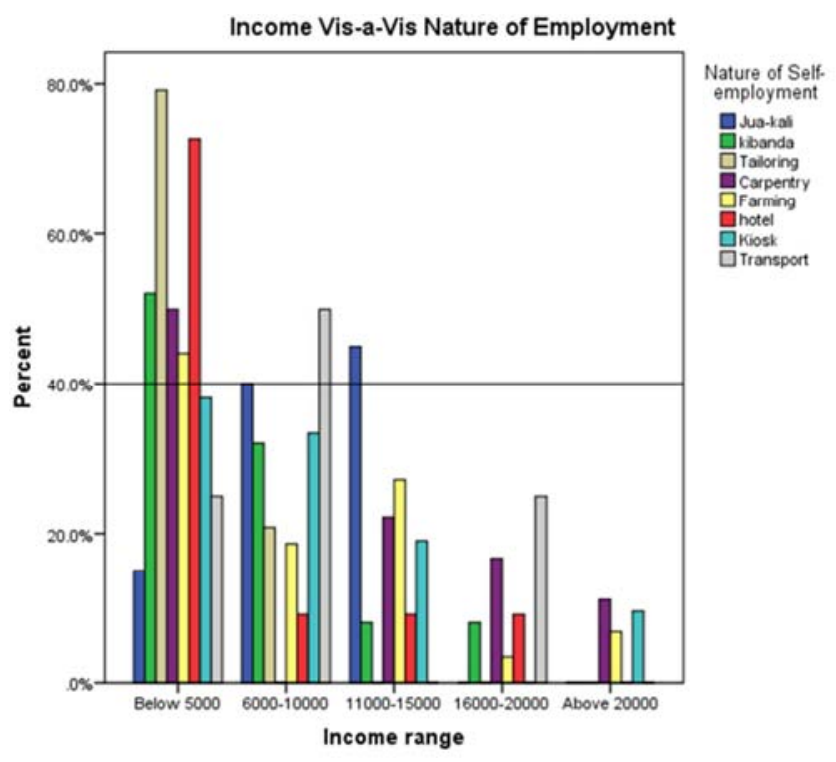

Figure 10. Income comparison.
It is evident that majority of the respondents are selfemployed in economic activities including farming, carpentry, tailoring, hotels, boda boda transport services among others. As indicated in figure 10, majority of the people (more than $40 \%$ ) earn below five hundred Kenya shillings per month with a very small number (less than 20\%) earning above twenty thousand Kenya shillings per month. This implies that a lot more needs to be done to boost the economy.

Land is an important resource because it is a factor of production. The average land size for the residents of Nambale (figure 11 and 12) is 1.2 acres. Field data analysis also shows that $82 \%$ of the people within Nambale town own land below 5 acres, followed by those who own between 6 and 10 acres at $10 \%$ with the least percentage by those who own land above 15 acres at $2 \%$.

This means that there are numerous sub-divisions probably because of the increasing population. The rampant subdivisions therefore mean that agricultural land is becoming less and less small thus not economically viable. This has a direct impact on food production and therefore the general economy of the area.

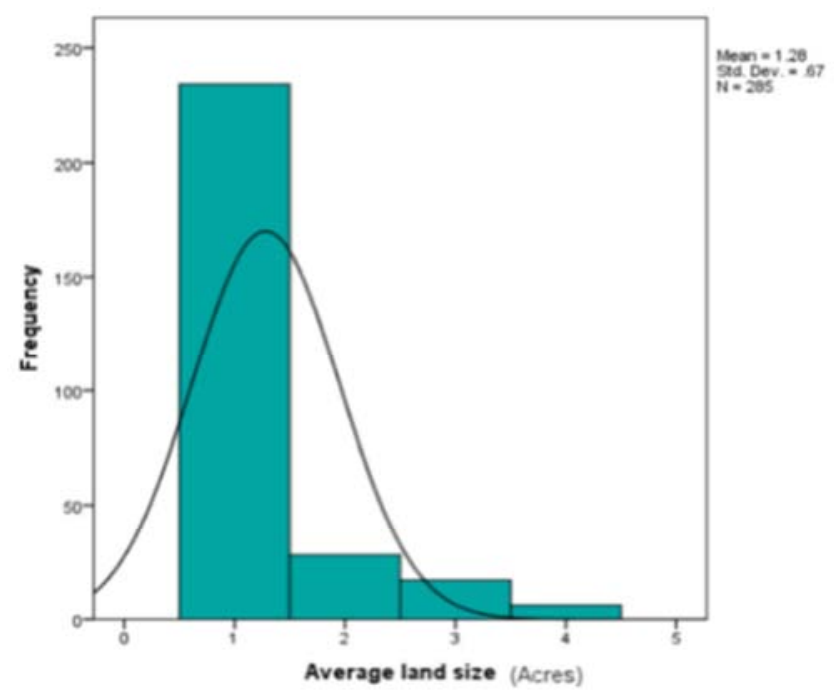

Figure 11. Average land size.

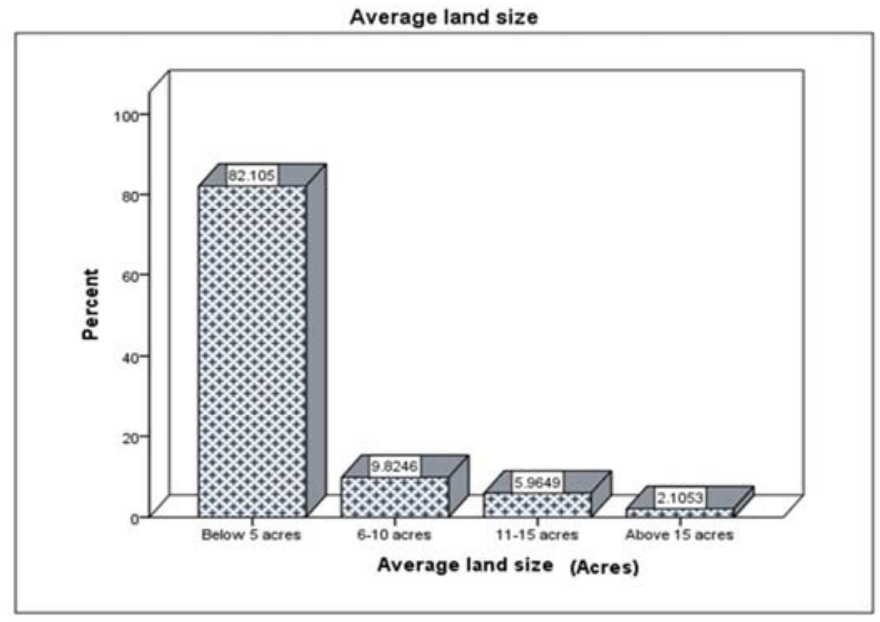

Figure 12. Average land size. 
Chapter five of the constitution of Kenya classifies land in three categories-Public land, Private Land and Communal land. The ownership of these categories of land can either be freehold or leasehold [11]. The most dominant land tenure system is freehold $(78 \%)$ followed by leasehold and communal at about
$10.7 \%$ each and Government land at about $0.6 \%$ (figure 12 ).

According to the data, Government land is limited and therefore not sufficient for public use. This implies that compulsory acquisition will be used if there is need to have more land for public use.

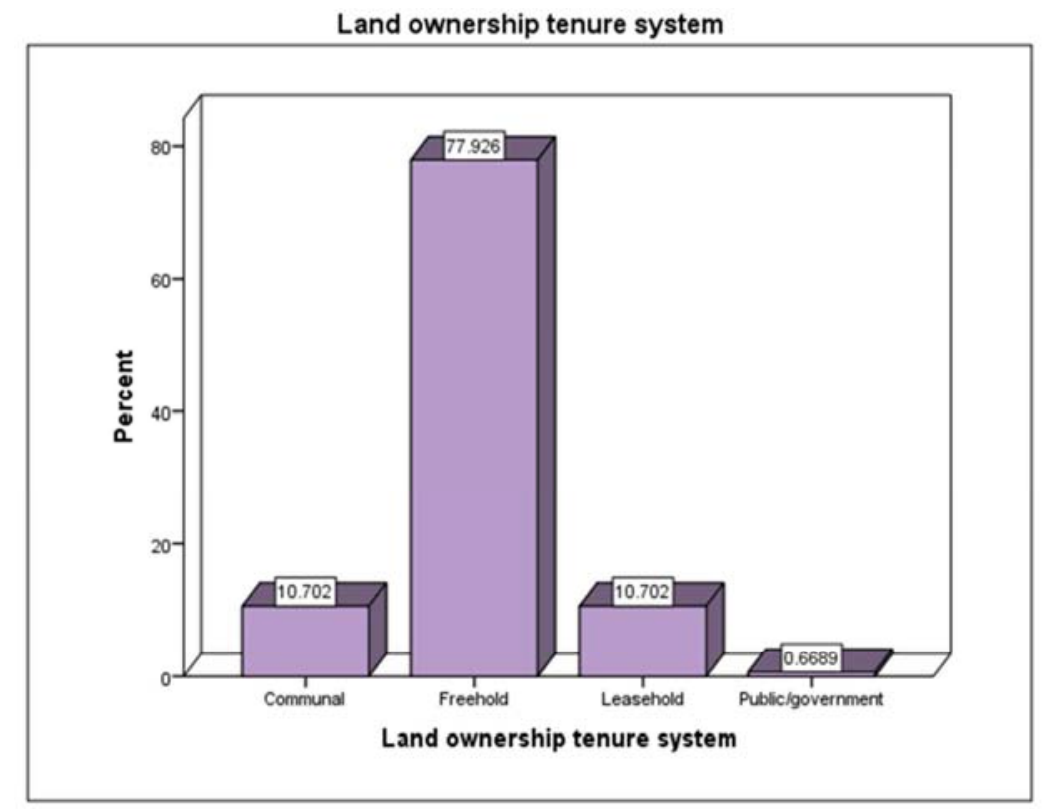

Figure 13. Land tenure systems.

The main land use in Nambale is agriculture intertwined with the following land use classes: commercial, residential (high density, medium density and low density), education and industrial. Mumias-Busia road is tarmacked, the rest of the roads on the map are earth roads. Three rivers flow through the town in the north-south direction. The total area covered by the study area is approximately 4300 hectares. Figure 14 presents the existing uses of land the Nambale study area.

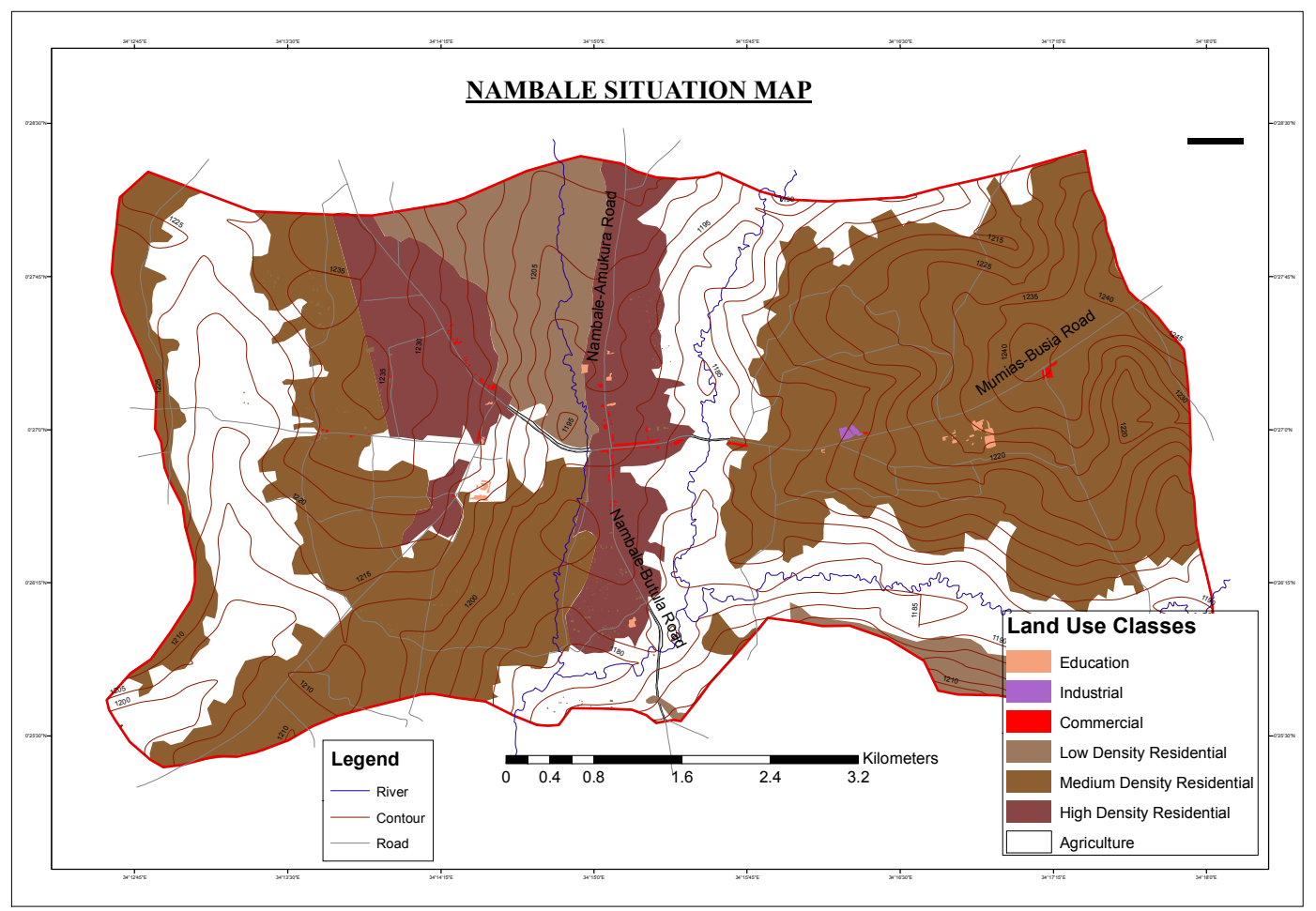

Figure 14. Existing situation in Nambale (Data source: Google Earth). 


\subsection{Sector Analysis}

\subsubsection{Education}

The study area had a number of educational facilities both public and private. The institutions comprise of pre-primary, primary, secondary and tertiary institutions. The major type of school within the planning area was mixed school followed by boys' school and girls' school the least. The analysis also shows that the maximum distance to educational facilities is $5 \mathrm{~km}$ with a majority of the facilities located at an average of $2 \mathrm{~km}$. The distances have a great implication in planning for the educational facilities.

Data analysis showed that most of the schools were within a distance of $2 \mathrm{~km}$ and below. It is however important to note that only two estates, Musoma and Ebusinda had the nearest primary school located above $3 \mathrm{~km}$.

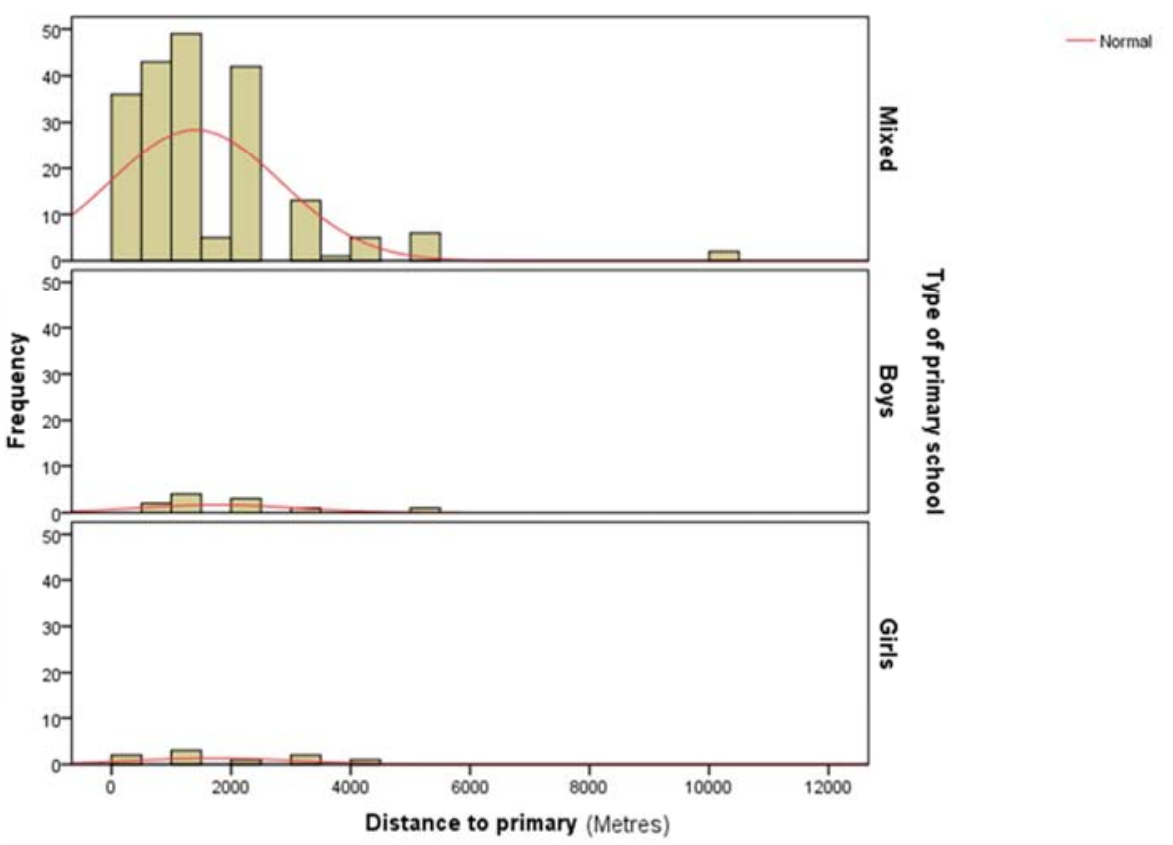

Figure 15. Distance to primary school.

The data collected also revealed that the education sector in Nambale is faced with a number of challenges including understaffing (42\%), insufficient learning materials (12\%), poor infrastructure $(8 \%)$, inadequate water and electricity $(8 \%)$, untrained teachers $(5 \%)$ and poor services $(2 \%)$. This is illustrated in the figure 17 below.

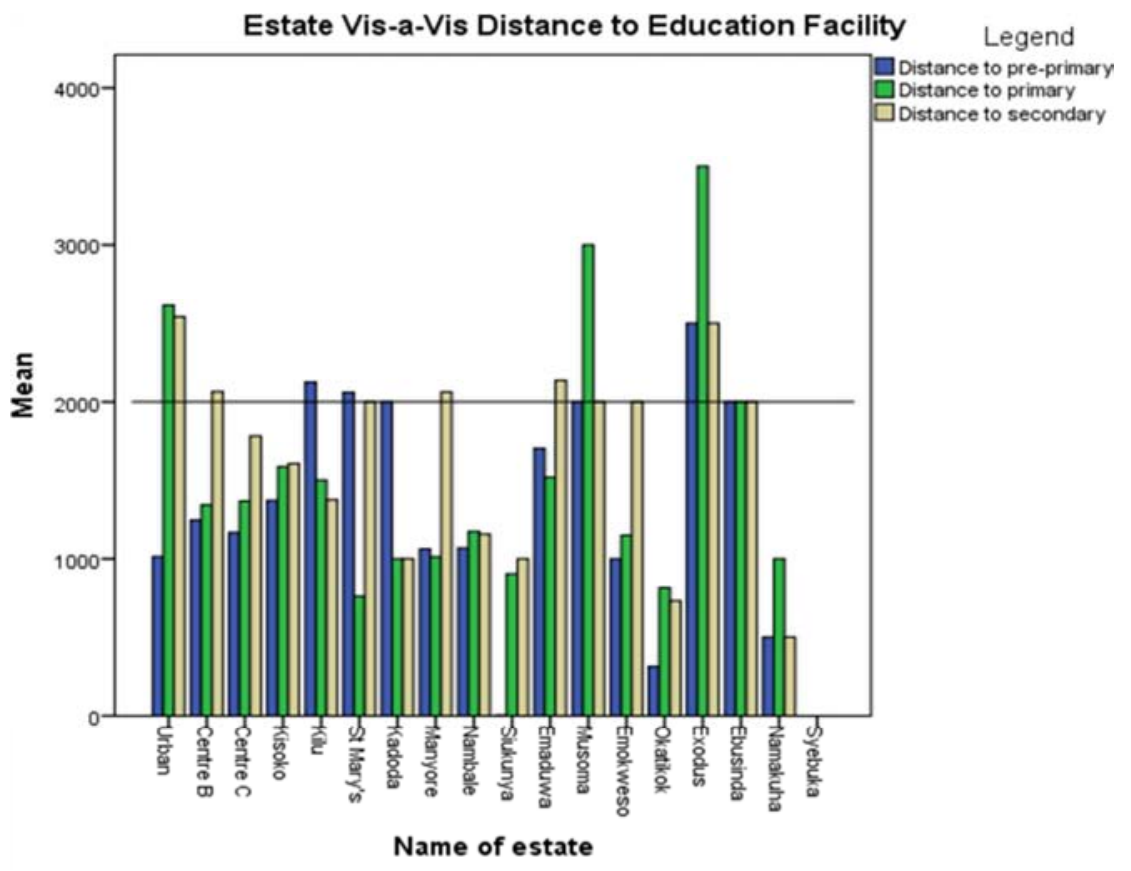

Figure 16. Comparison of estate and distance to Education facilities. 


\section{Challenges Facing Education}

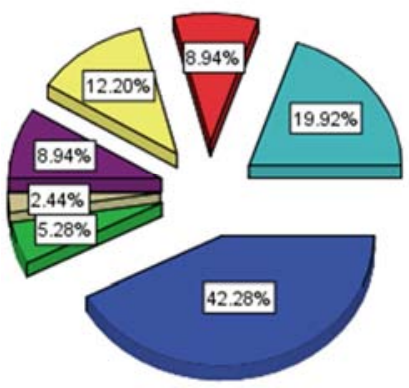

Figure 17. Challenges facing Education sector.

\subsubsection{Economic Activities}

The main economic activities in Nambale include Agriculture, livestock and trade. This implies that majority of individuals in Nambale are farmers and this could be due to the soils and climatic conditions that favor cultivation of a variety of crops.

Nambale Sub-County has the most fertile land and is also the leading producer in agriculture within Busia County. The major crops grown in Nambale are maize, cassava, beans, millet, sweet potatoes and sorghum. The cash crops grown include sugarcane, cotton, palm tree, ground nuts, bananas, tomatoes (horticulture), onions, and vegetables. Some of the major problems faced by farmers during production include the following: lack of mechanization; rampant land subdivision therefore decreasing size of agricultural land; scarcity of certified seeds; high prices of seeds; acidic soil due to continuous use of Diammonium Phosphate fertilizer; marketing challenges due to lack of organization among farmers hence low prices of farm products; and understaffing especially within the Department of Agriculture at the county level therefore the number of Agricultural Extension Officers is not adequate.

Livestock keeping is another major economic activity within the study area. The table below shows the production of various types of livestock within Nambale town.

Table 1. Livestock production (Source: Busia County).

\begin{tabular}{lll}
\hline Livestock & Number & Production \\
\hline Cattle: beef & 37494 & $16200 \mathrm{kgs}$ \\
Dairy & 4022 & $649406 \mathrm{ltrs}$ \\
Sheep: wool & 0 & 0 \\
Hair & 7554 & $1800 \mathrm{kgs}$ \\
Goat: dairy & 81 & 0 \\
Meat & 110262 & $2700 \mathrm{kgs}$ \\
Pigs & 12983 & \\
Poultry: broilers & 500 & \\
Layers & 7270 & $1,678,488 \mathrm{eggs}$ \\
Indigenous & 220966 & \\
\hline
\end{tabular}

The most common type of urban agriculture was subsistence farming at 59\%. Other types included cash crop farming (14\%), livestock keeping (7\%), and horticulture at $1 \%$. Another activity also practiced within Nambale town includes forestry at $2 \% .17 \%$ of those interviewed did not practice any form of urban agriculture.

\section{Types of urban agriculture}

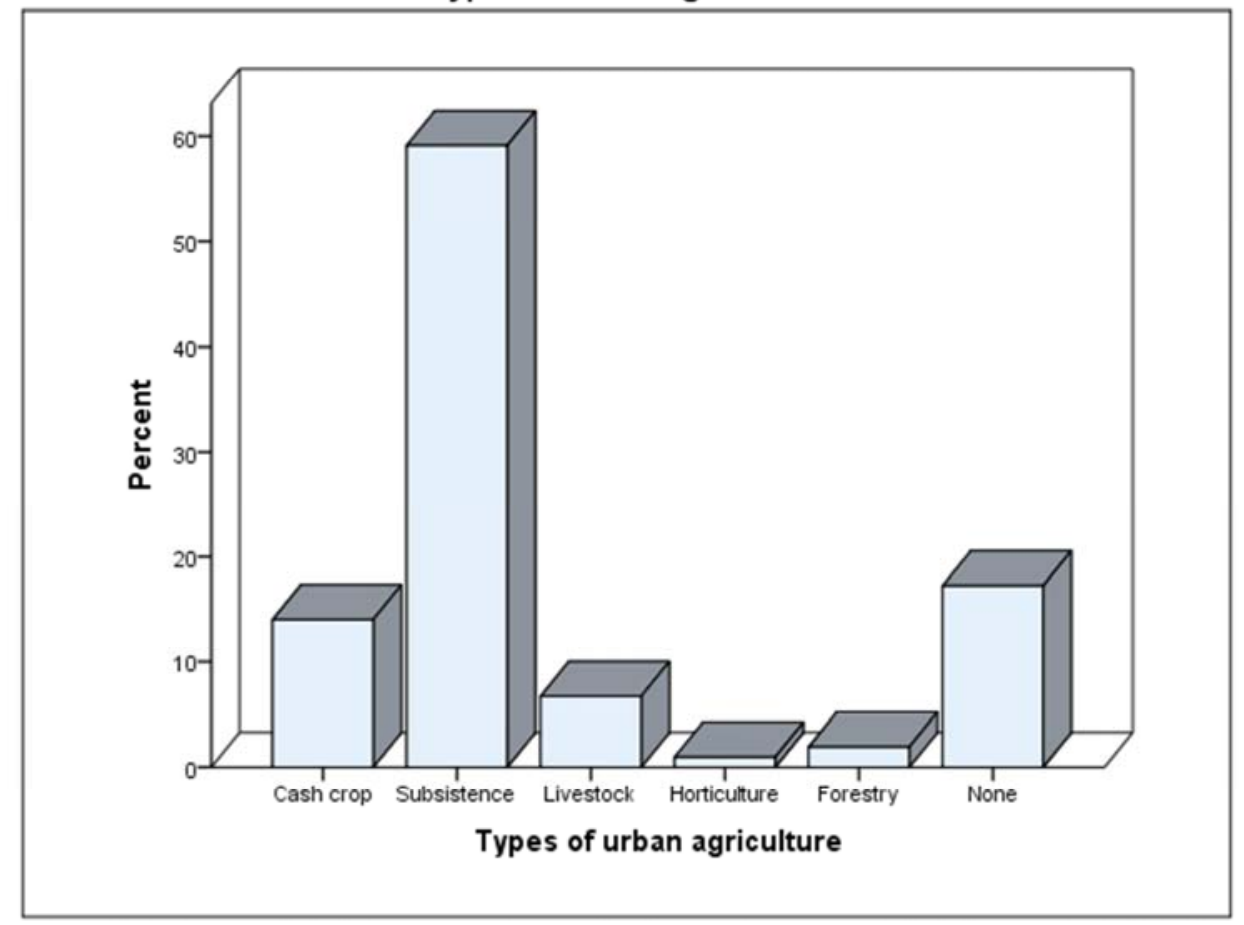

Figure 18. Urban Agriculture in Nambale. 
Some of challenges facing livestock production within Nambale are inconsistency in supply of feeds, diseases such as Newcastle which are vector-borne, inadequate extension officers, poor breeding systems for instance in poultry farming, expensive artificial insemination services which are not readily available, low adoption of new techniques, biasness due to land use pressure (use land for crops than animal production), inadequate market linkages and market sourcing, poor planning and reluctance for acquiring funds through loans.

\subsubsection{Commercial Activities}

Commercial activities practiced within the planning area include shops (33\%), open air kiosks (30\%), supermarkets $(29 \%)$, hotels $(4.4 \%)$ and whole sale shops at $1.4 \%$. This is illustrated by the figure 19 below. The major challenges affecting access to the market accessibility include overcrowding (42\%) and poor sanitation (23\%). 33\% of the respondents however stated that they face other challenges including lack of lighting and insufficient water. $23 \%$ of the respondents stated that there is no challenge.

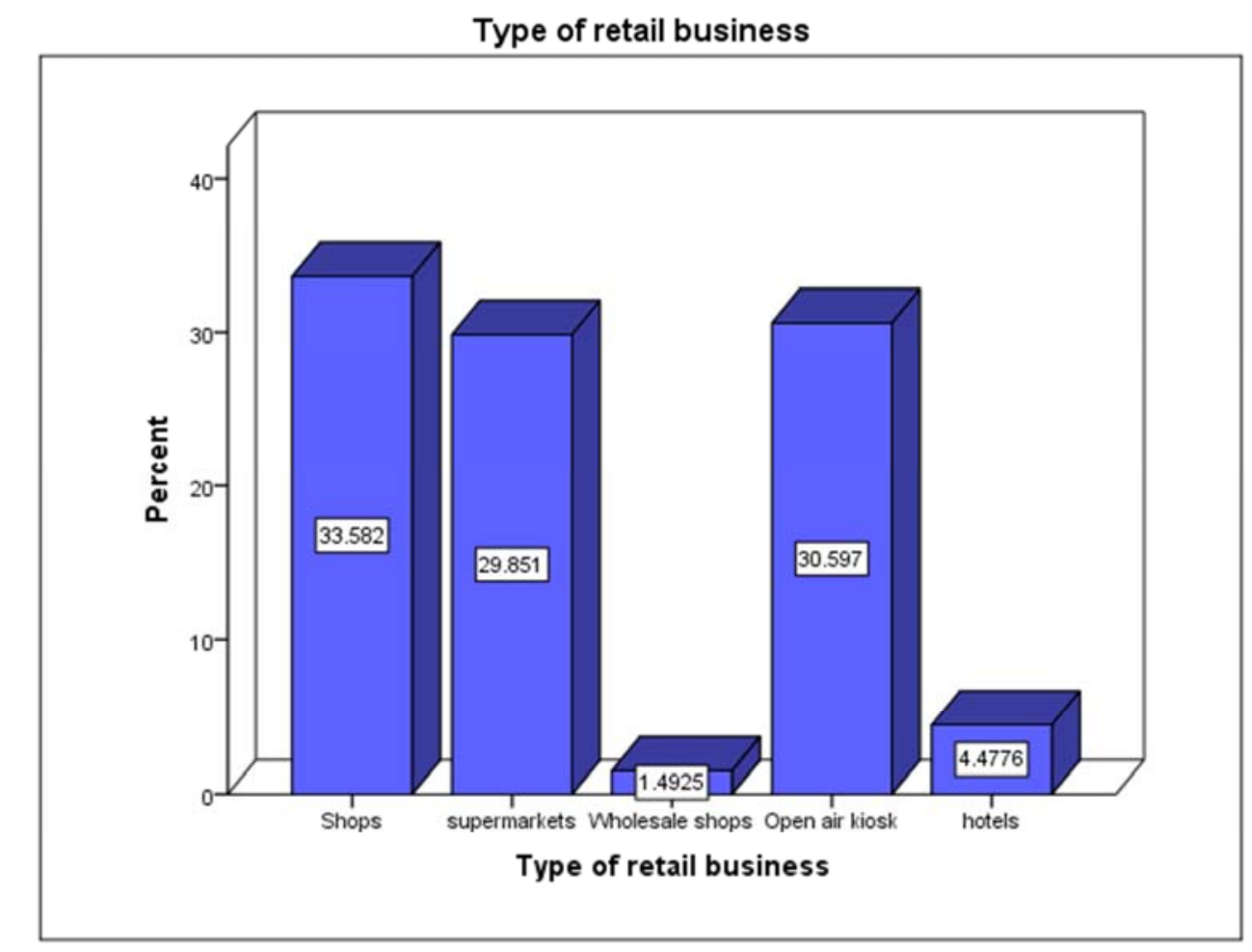

Figure 19. Retail Businesses in Nambale.

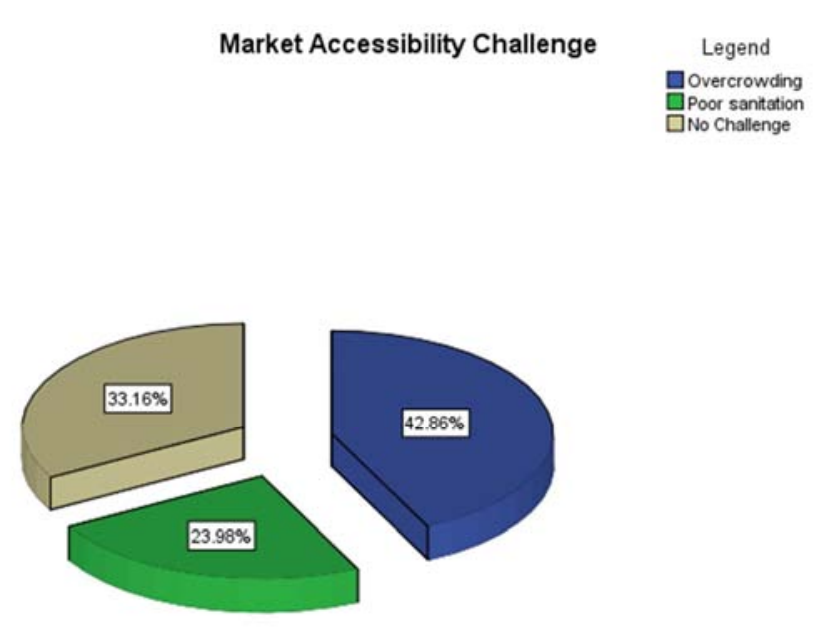

Figure 20. Market Accessibility Challenges.

\subsubsection{Housing}

Housing is a basic need and also one of the components of the 'big four agenda' by the Government of Kenya [12]. Housing presents itself in different forms and structures. This is mostly dependable on a person's socio-economic status. Housing exists in three modes: permanent, semi-permanent and temporary. The rich live and have their operations in well-built structures, whereas, the poor live-in low-cost housing with poor facilities.

Housing in Nambale was classified to be either permanent, semi-permanent or temporary. The classification was based on the nature of the material used for construction for the roof, wall and also the floor. According to the field data analysis, $94 \%$ of those interviewed used iron sheets, $1 \%$ used roof tiles while $5 \%$ used grass/papyrus as roofing material. Others included polythene bags etc. The material used for wall were $41 \%$ for bricks, $38 \%$ mud, $15 \%$ stones, $4 \%$ iron sheets and $2 \%$ timber. Others included polythene bags and papyrus reeds.

The floors were made of concrete/cement (57\%), mud $(30 \%)$ and tiles $(13 \%)$. 


\section{Roof type}

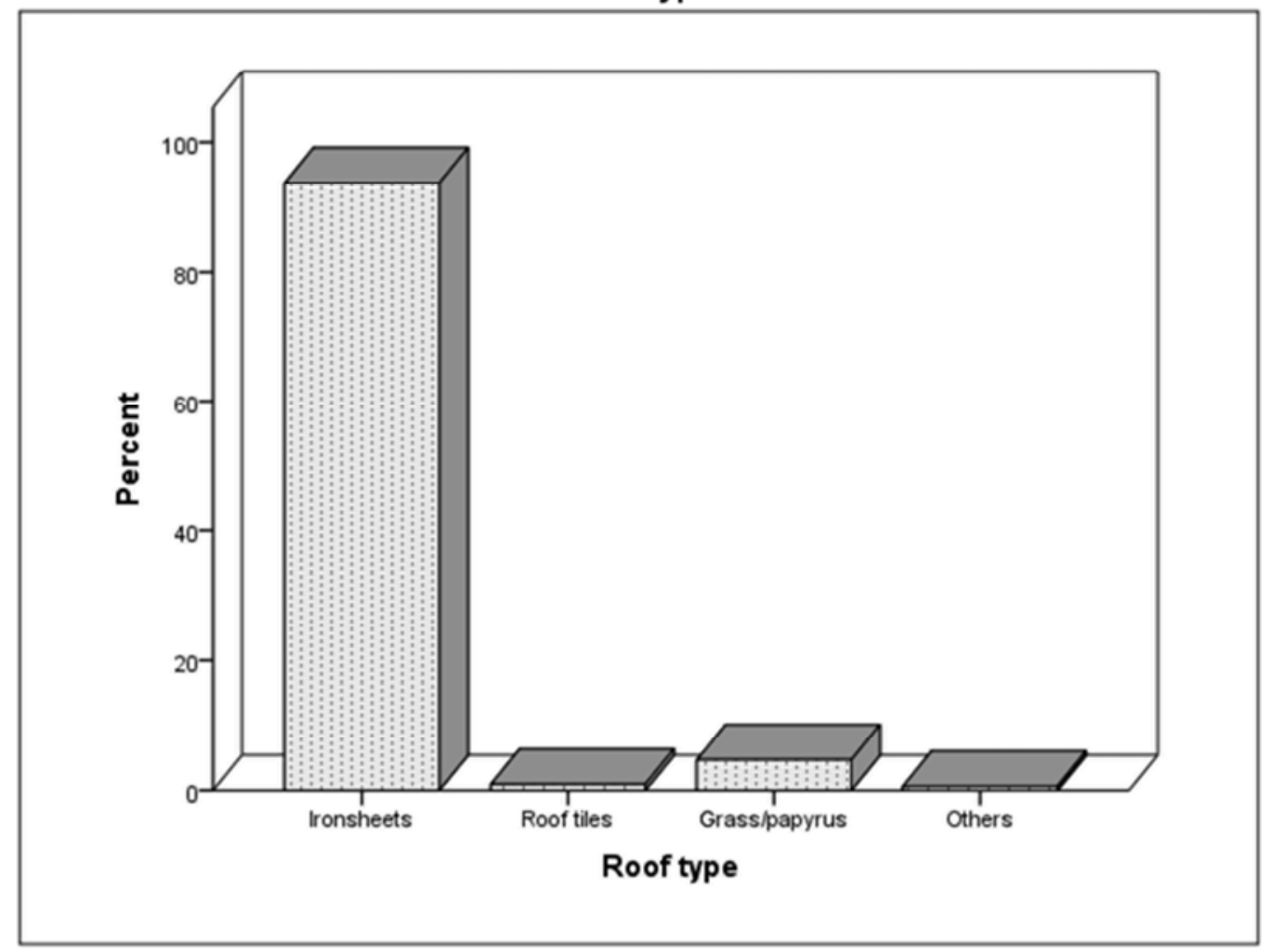

Figure 21. Housing Typology, Roof Type.

\section{Floor Type}

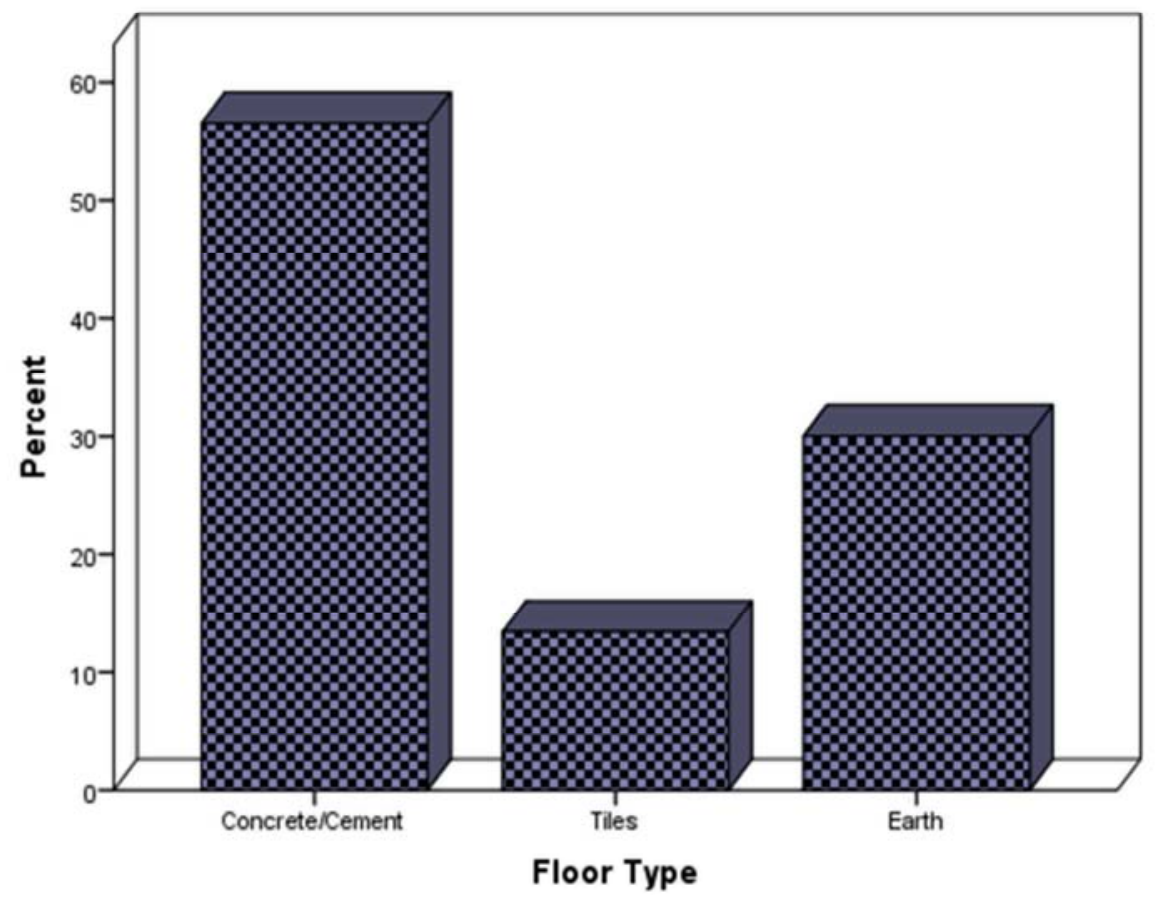

Figure 22. Housing Typology, Floor type. 


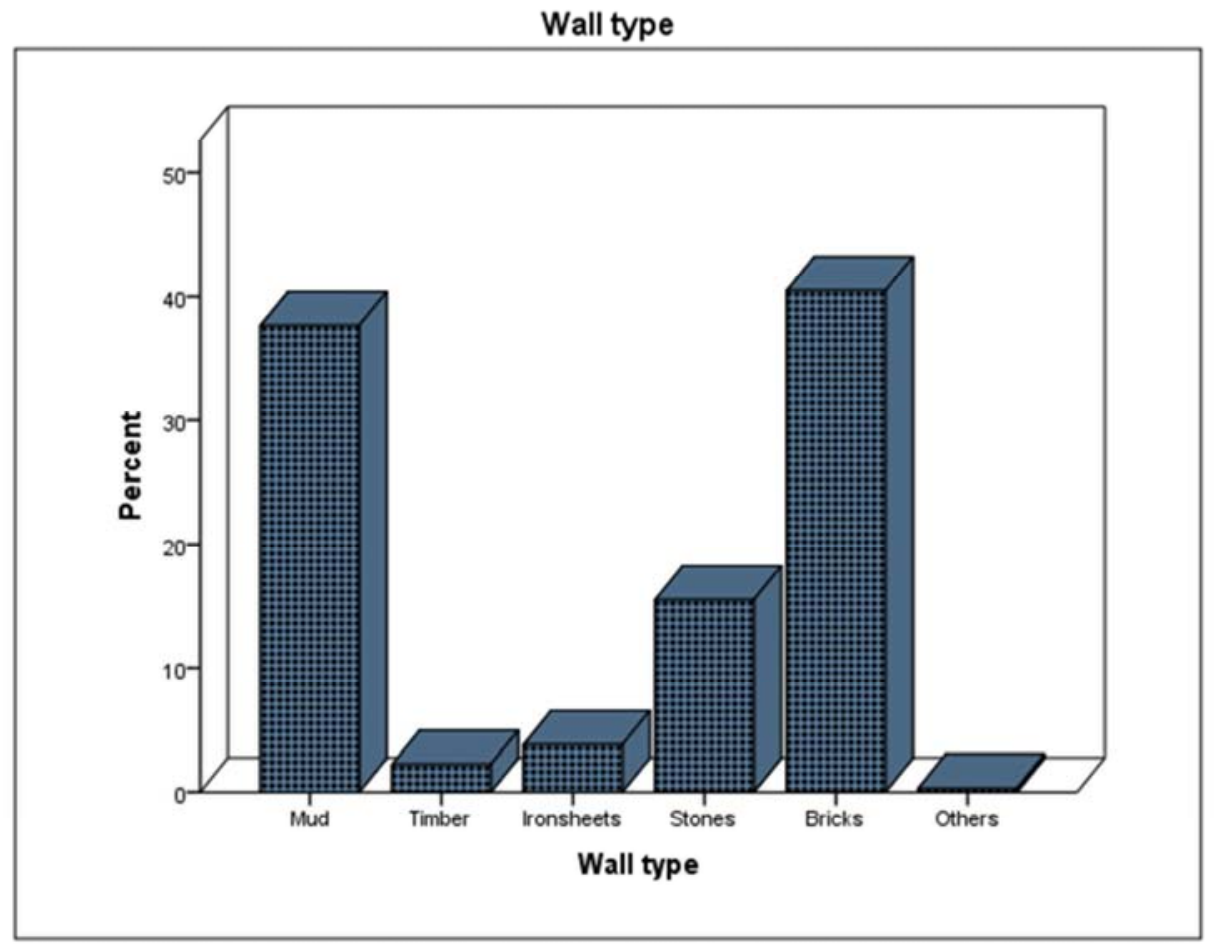

Figure 23. Housing Typology, Wall type.

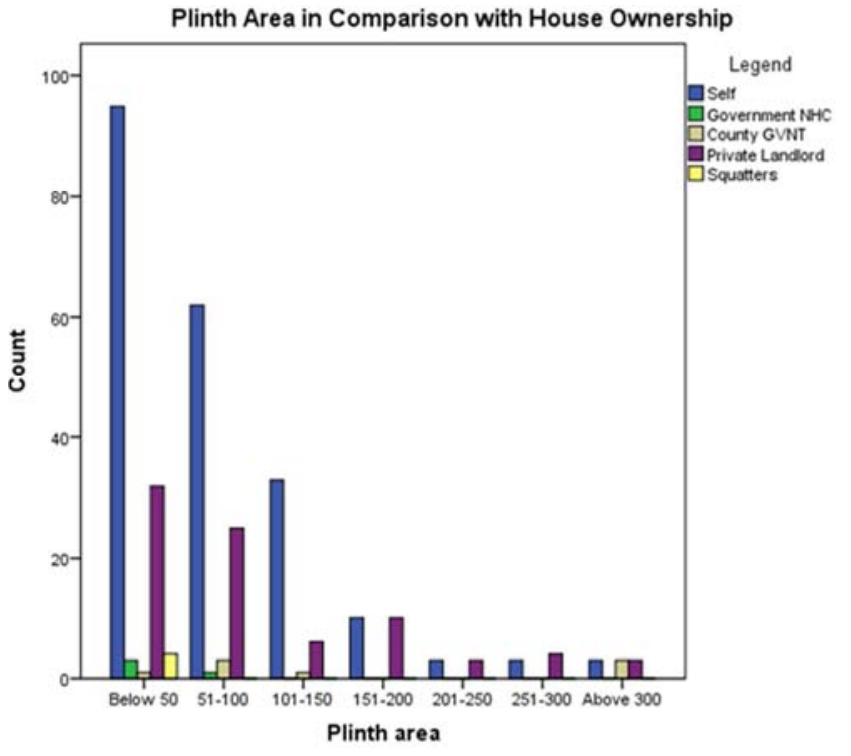

Figure 24. Plinth Area and House ownership.

From the data analysis, it was found that the plinth area for self-owned housing units was bigger than the housing units for the Government and for those owned by private landlords. According to figure 24 above, there were few housing units with a plinth area above $150 \mathrm{~m}^{2}$.

According to the respondents, there are a number of housing challenges within Nambale town. They include lack of amenities (49\%), poor house quality (18\%), high rent (8\%) and inadequate housing (7\%). $15 \%$ of those interviewed stated that they face no challenge. Others include cases of insecurity, accessibility etc.

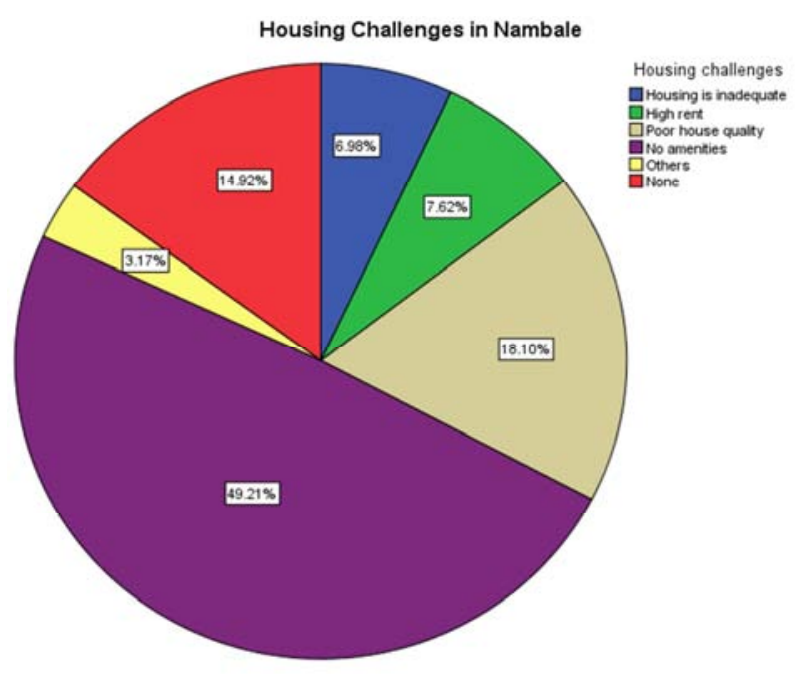

Figure 25. Housing Challenges.

\subsubsection{Health}

UN's sustainable development goal number three strives to ensure healthy lives and promote well-being for all at all ages by the year 2030 [13]. We all know how important it is to be in good health. Our health affects everything from how much we enjoy life to what work we can perform. The wellbeing of human life rests most importantly on the attainment of good health and a healthy population is usually productive. This section highlights and gives an analytical explanation of the programs and aspirations in the health sector as well as the health services and facilities present in Nambale. The limitations of the health service provision to the community are also discussed at length. 
Figure 26 below shows the analysis of the distances of various estates to the various types of health facilities within Nambale town which include Sub-county hospital, health centre, dispensaries and clinics. The statistics show that most of the health facilities which include clinics, dispensaries and the major sub-county hospital (Nambale sub-county hospital) are located at an average distance of $2 \mathrm{~km}$.

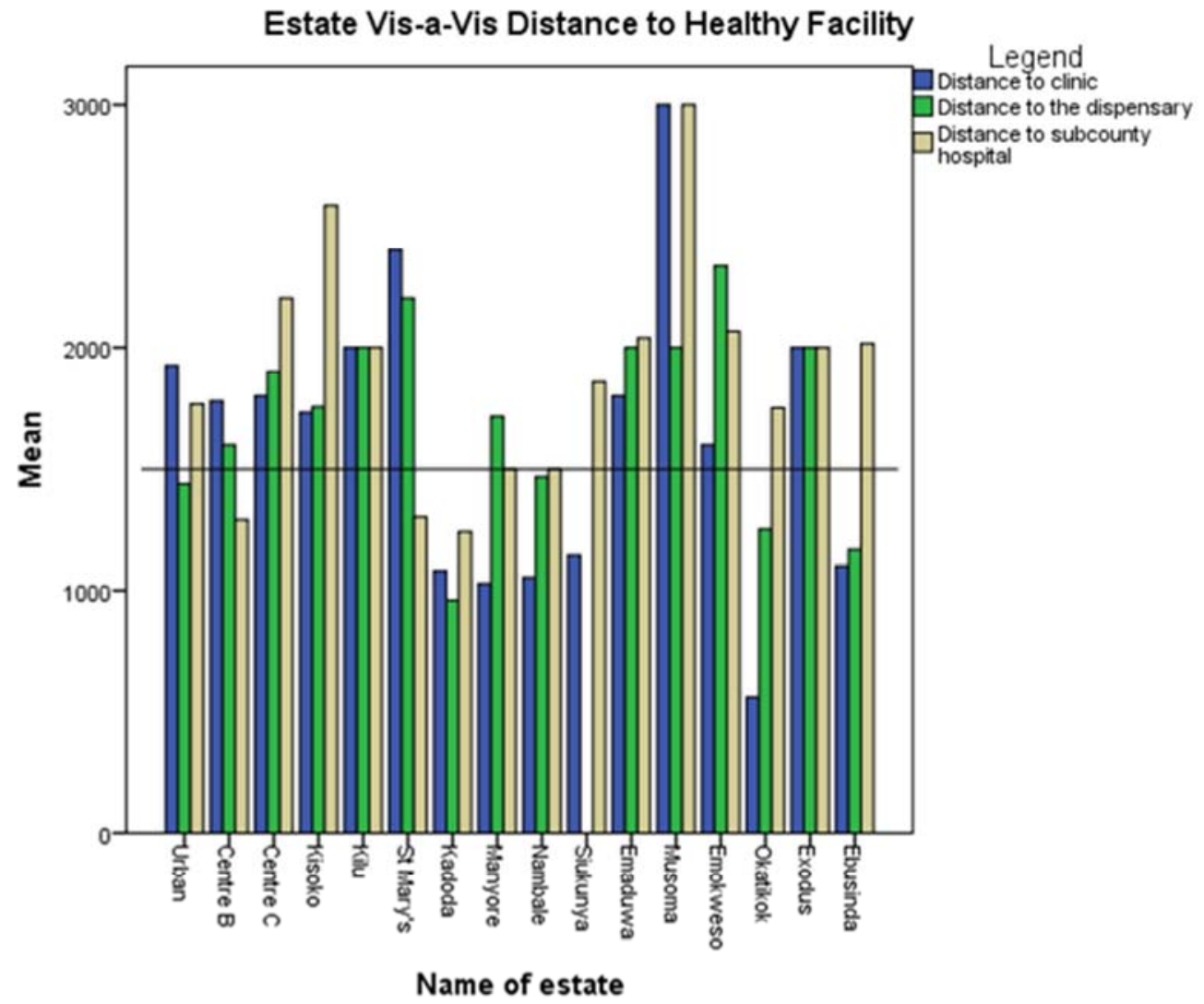

Figure 26. Comparison of Estate and Distance to Health Facility.

The health sector within Nambale town faces a number of challenges. They include inadequate medicine (42\%), inadequate staff $(25 \%)$, inadequate hospitals (11\%), inadequate equipment $(9 \%)$, expensive services $(9 \%)$ and poor maintenance of buildings $(3 \%) .2 \%$ of the respondents stated that there were no challenges facing the health sector.

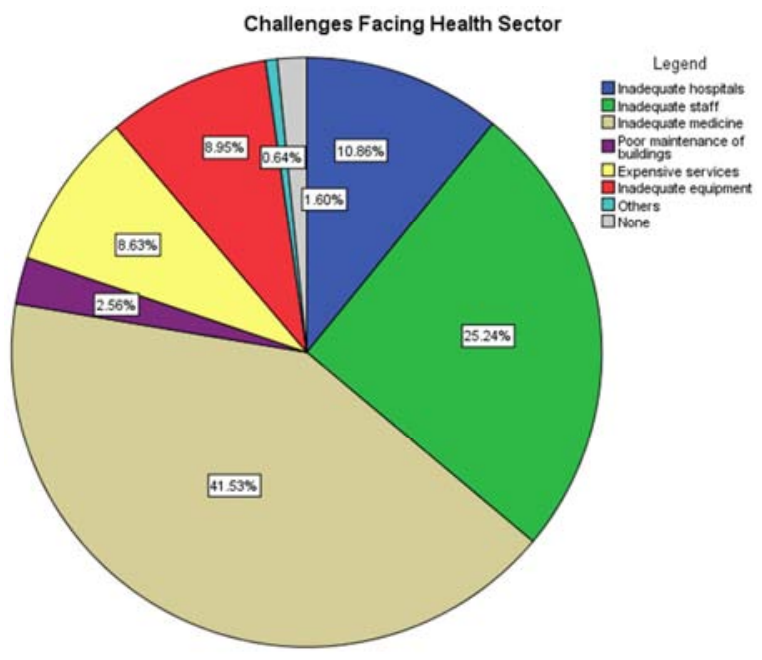

Figure 27. Challenges Facing Health Sector.

\subsubsection{Transport}

Transport sector is the major driver to economic growth. The transport system in Kenya encompasses six modes of transport namely-Road, Rail, Air, Maritime and Inland Water, Pipeline, Non-Motorized and Intermediate Means of Transport. The transport system in Nambale is dominated by road transport. Air and Rail transport terminals are not present within the planning area thus those modes currently play a minimal role in providing access or transportation of goods and services to and from Nambale.

The major road that passes through Nambale town is a tarmac road that connects Busia town to other towns including Bungoma and Mumias. The other major road is an earth road that connects Nambale town to Butula town and Malaba. Within the planning area, the road under tarmac covers a distance of $8.1 \mathrm{~km}$ while the major earth road connecting Butula to Amukura covers a distance of $5.4 \mathrm{~km}$.

Field data analysis revealed that the main means of transport within Nambale was motorcycles popularly known as bodaboda. This accounts for $64 \%$ followed by use of matatus at $25 \%$, bicycles at $5 \%$, travelling by foot at $4 \%$ and the use of bus at $2 \%$. The high use of motorcycles therefore demands for the provision of motorcycle paths. A summary of the main means of transport is indicated by figure 28 . 


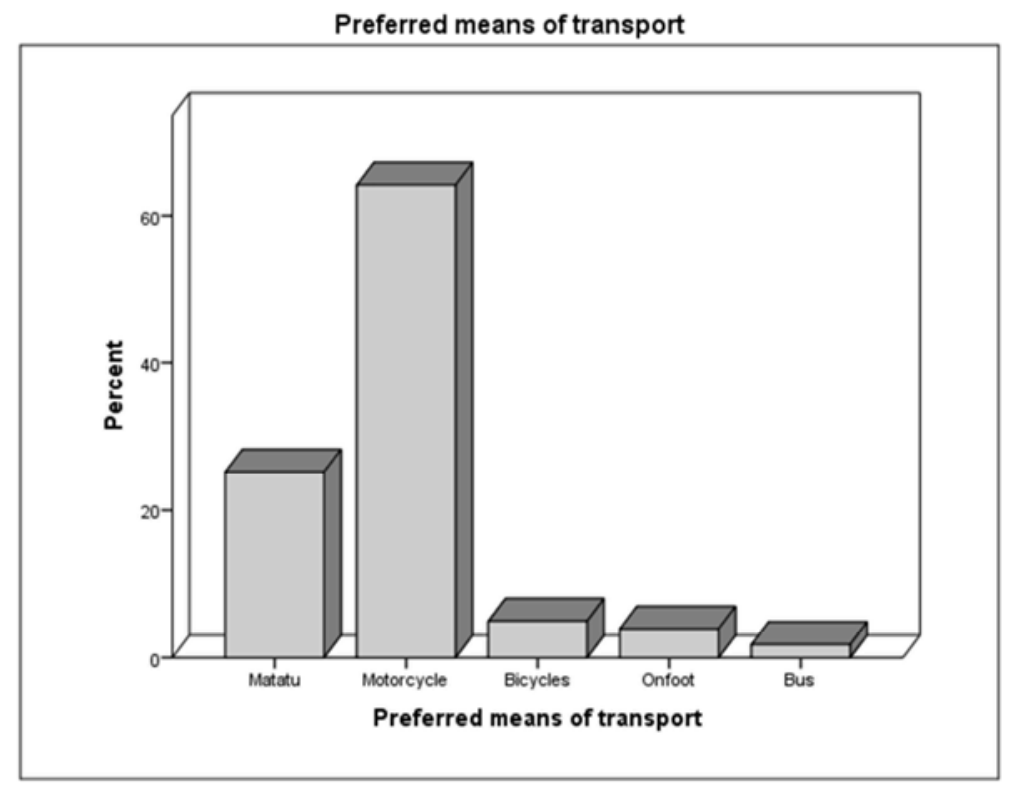

Figure 28. Preferred means of transport.

Road transport within the planning area faces a number of challenges. Poor state of roads especially the feeder roads, narrow roads, encroachment into road reserves and lack of parking for boda bodas leading to parking along road reserves are some of the challenges.

The County of Busia runs the following programs related to road development within Nambale: Opening of new roads, routine maintenance of existing roads and also upgrading of major roads to bitumen standards.

\subsubsection{Energy}

Energy is an important driver for the growth of an urban centre. It is used for lighting, cooking or use in home appliances and also for industrial use. Energy used by different household greatly varies depending on many aspects such as affordability and accessibility. The UN sustainable development goal number seven advocates for affordable and clean energy [13]. People of Nambale have different preferences and reasons concerning their choice of energy.

The main source of energy for lighting in Nambale is electricity followed by the use of solar energy and finally paraffin. The analysis also showed that the cost for each of the three sources of energy does not exceed five thousand shillings per month. This popularity of electricity for lighting could be due to introduction of rural electrification program in Kenya [14].

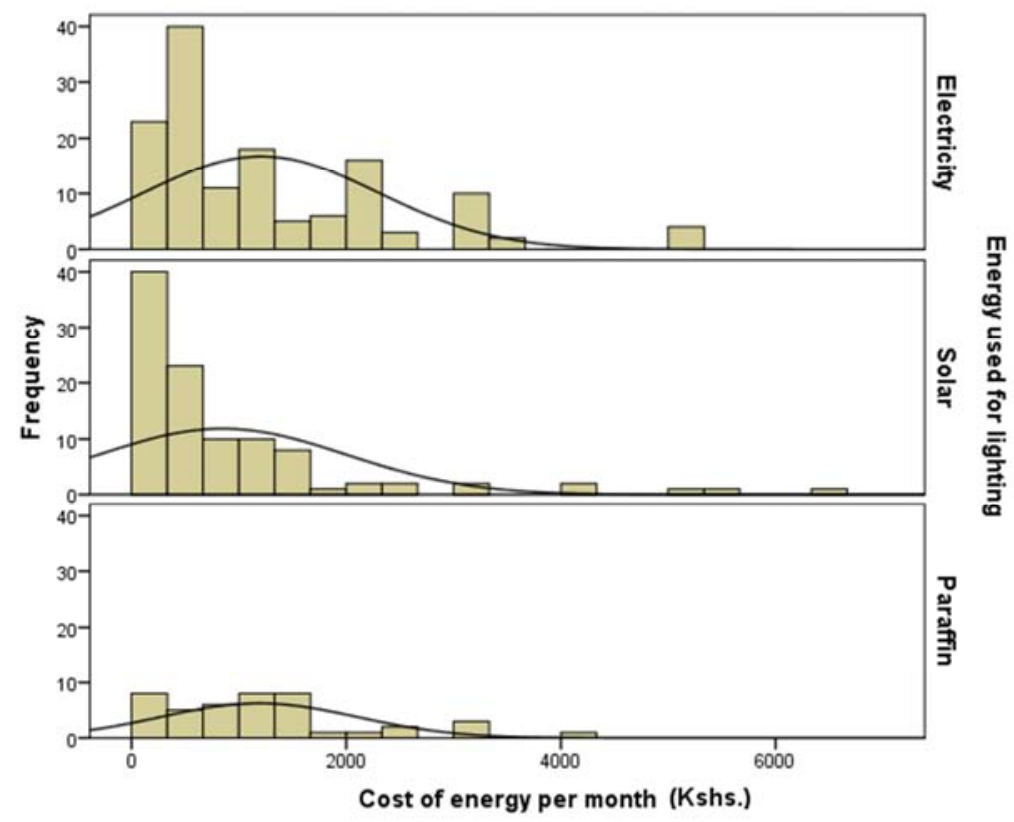

Figure 29. Source of Energy for Lighting and Cost. 
Data from the field survey revealed that the major source of energy for cooking is firewood followed by the use of charcoal and then paraffin. There was also the use of gas though by very few people. The high rate of use of firewood and charcoal therefore means that forests are endangered and therefore alternative means of use of clean energy should be encouraged to ensure that trees are conserved.
Analysis from the study also revealed that $47 \%$ of the respondents had frequent power blackouts as the major challenge. Other challenges include high cost $(23 \%)$ and fluctuating weather patterns (16\%). $13 \%$ of the respondents stated that there are no challenges in the energy sector (figure $31)$.

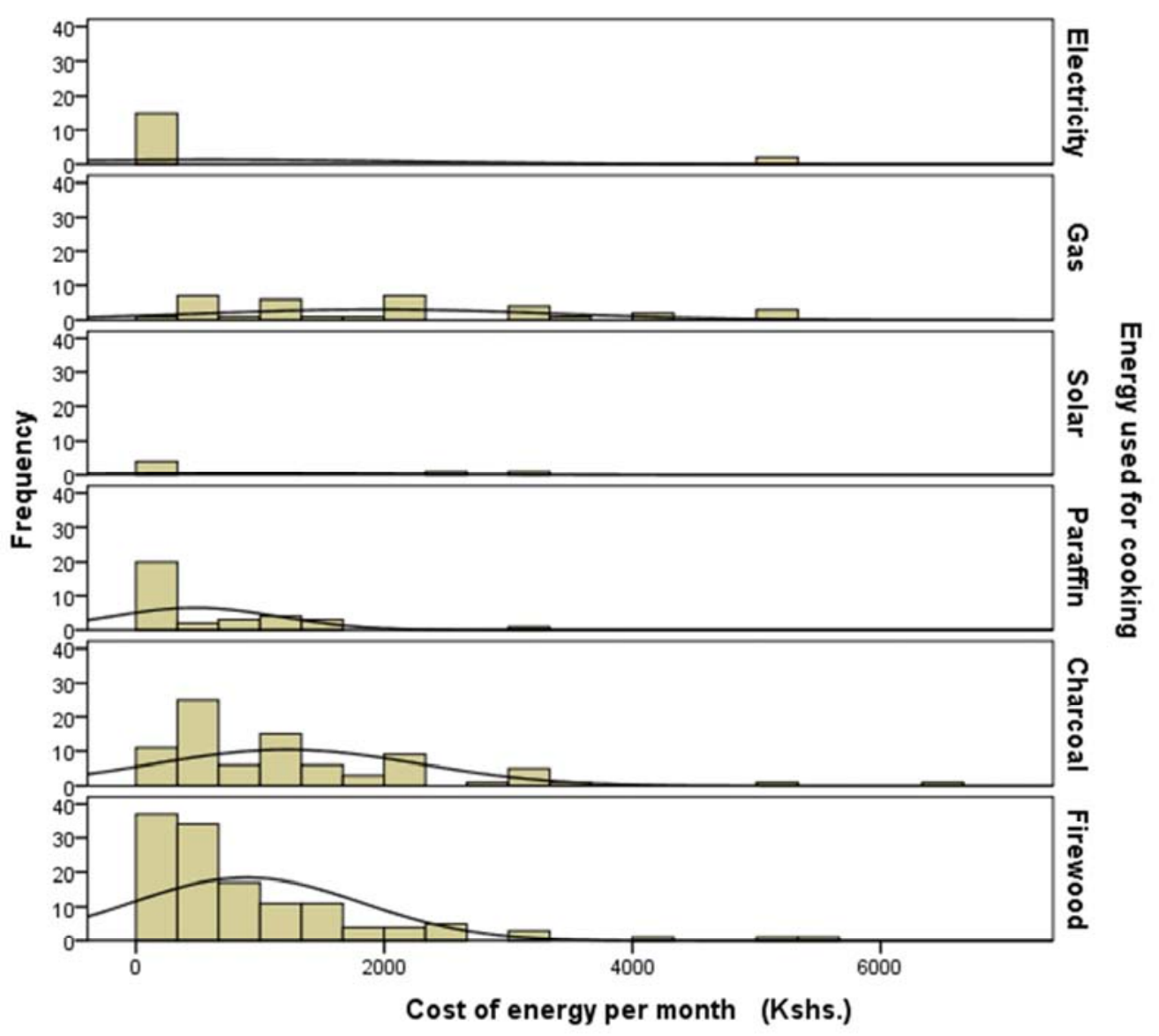

Figure 30. Cost of Energy for cooking.

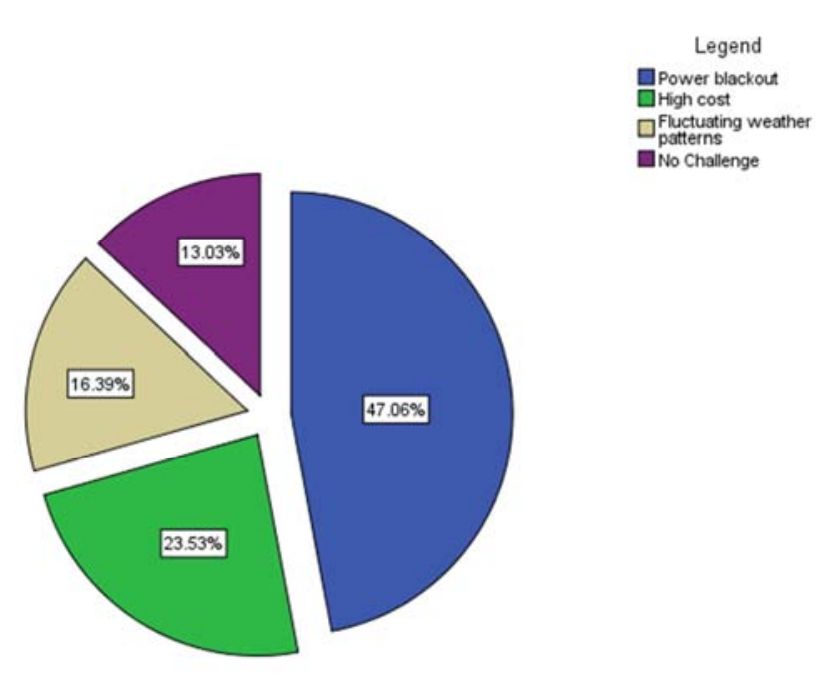

\subsubsection{Security}

Security provision is one of the major determinants to economic growth of a region. Enhanced security provides a good working environment and therefore acts as a catalyst for the other sectors of the economy.

According to the respondents, some of the major security challenges included delayed police response (52\%), fewer number of police officers (24\%), corruption (15\%), inadequate facilities $(6 \%)$ and poor housing for police officers at $0.5 \%$. This is depicted by the figure 32 below.

Some of the measures proposed by the respondents to address the challenges were increasing the number of police (45\%), improvement of police response $(42.9 \%)$, provision of street lighting (9\%), and purchase of more equipment to be used by the security personnel $(2.9 \%)$.

Figure 311. Challenges in the Energy Sector. 


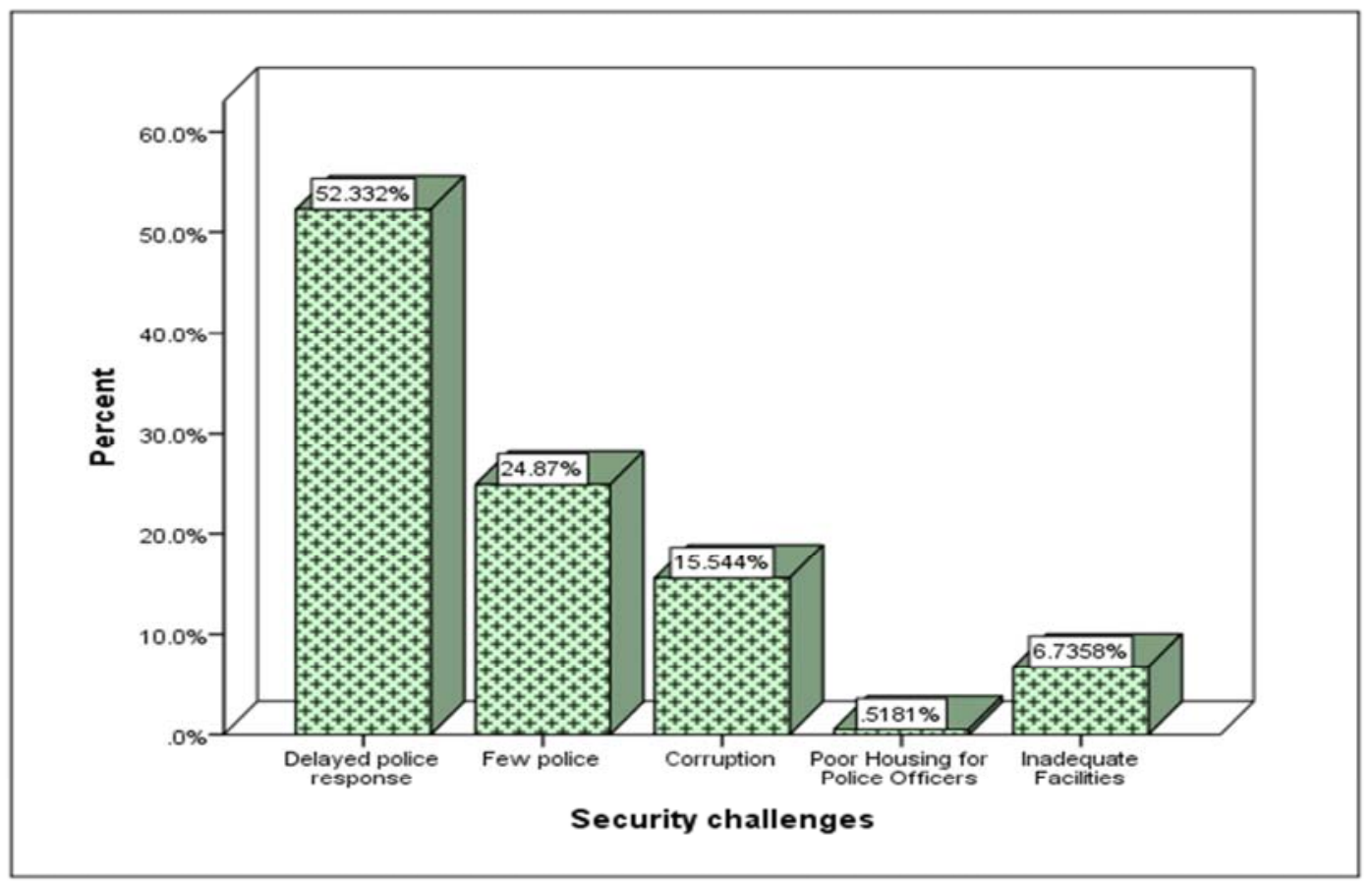

Figure 32. Security Challenges in Nambale.

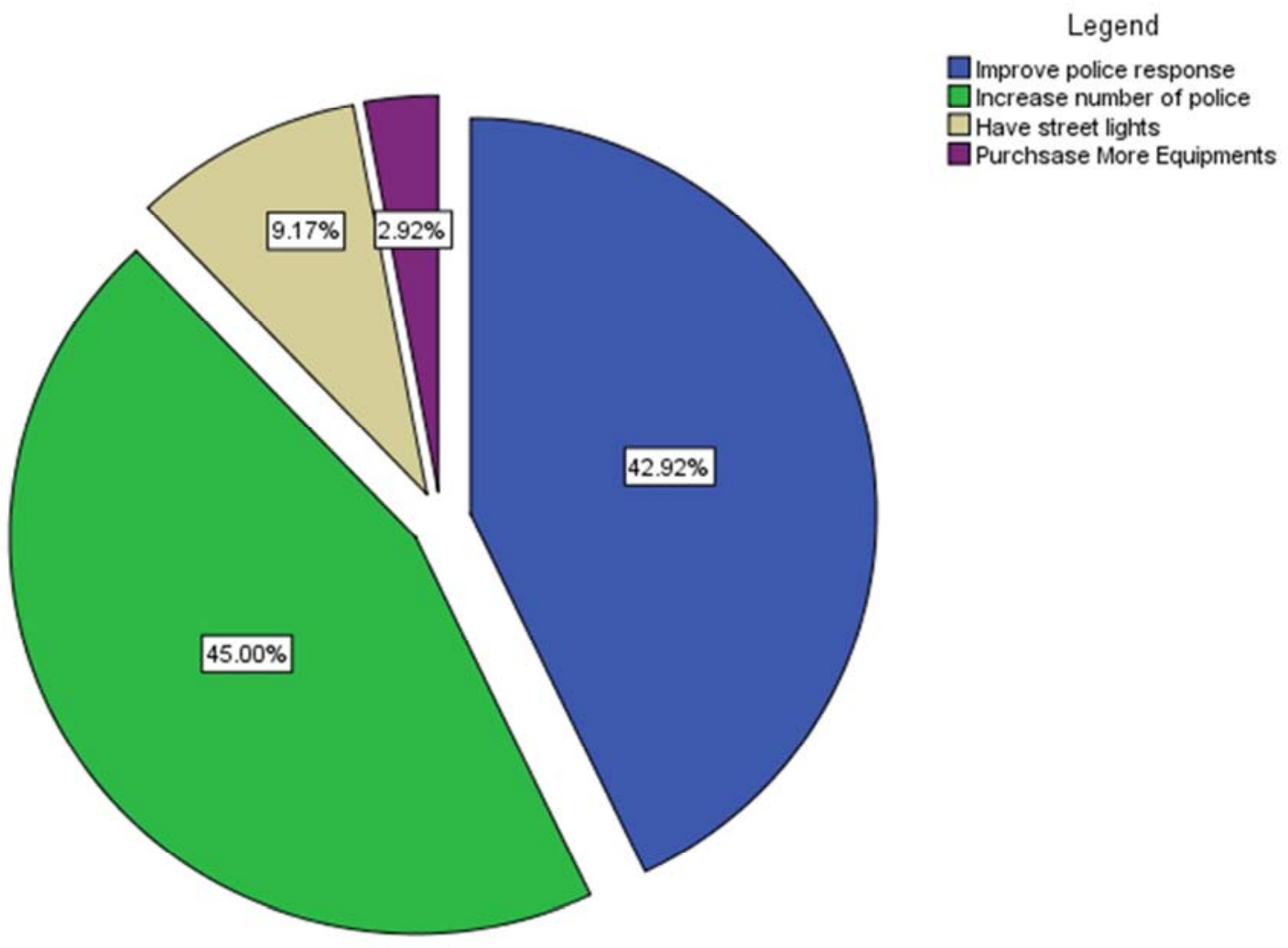

Figure 33. Measures to Address Security Challenges.

\section{Distances of estates to social amenities}

An analysis was done to ascertain the distances of various estates within Nambale town to some of the social amenities which include recreational facilities, security facilities, markets, workplaces and administration offices. Distances of the estates to water sources were also accessed. According to the data, most of these facilities are below $2.5 \mathrm{~km}$. This therefore means that these facilities are within reach but a lot more needs to be done to facilitate more accessibility by bringing services closer to the people. 


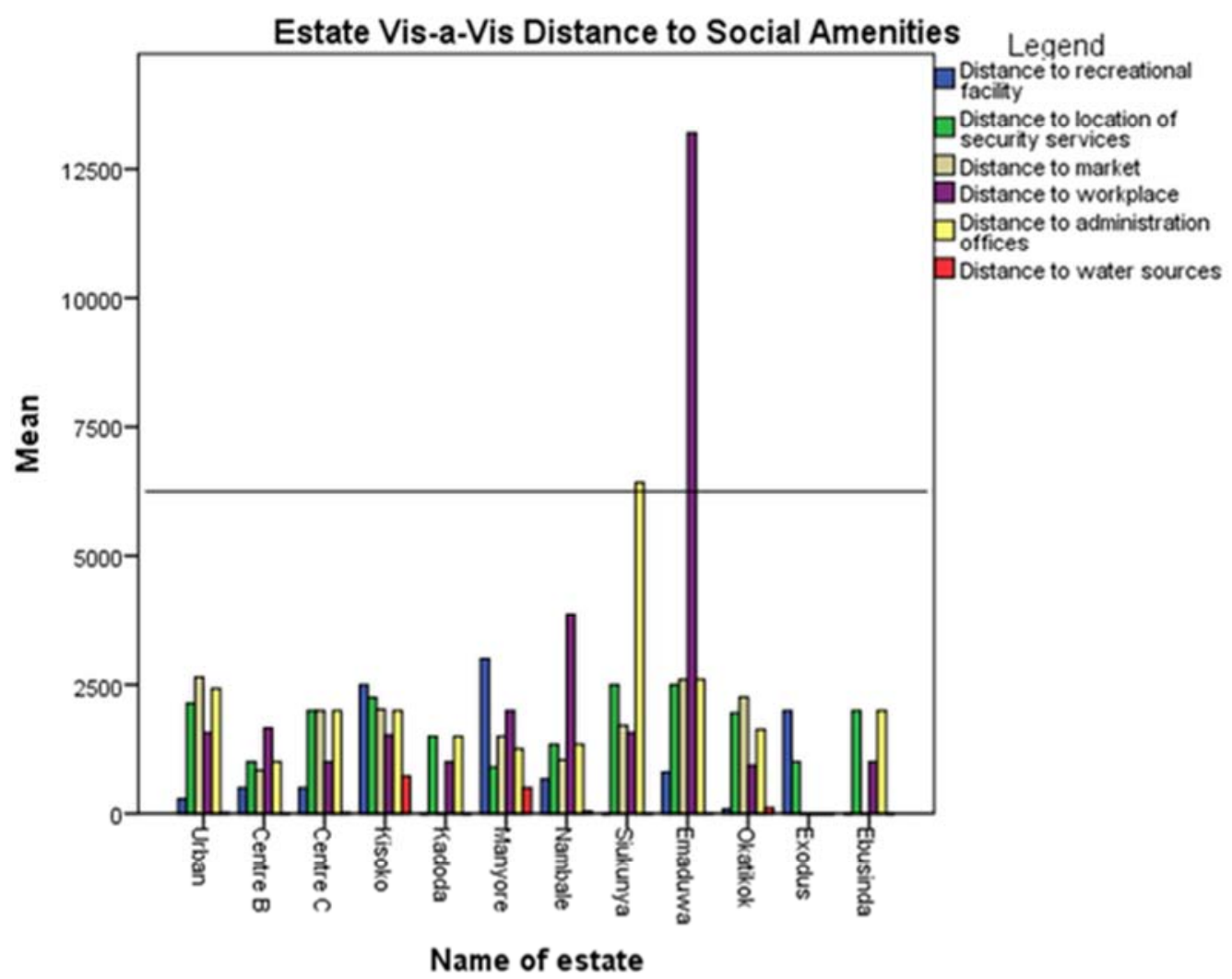

Figure 34. Estate and Distance to Social Amenities.

\subsubsection{Water}

The main source of water for Nambale residents is wells. Others include boreholes, piped water, rivers and springs. The most unreliable source of water was piped water. This therefore means that adequate measures need to be put in place to provide adequate water to residents of Nambale town.

The data collected indicate that $38 \%$ of the residents stated shortage of water as the main challenge while $23 \%$ cited drying of wells as a problem. Other challenges included unclean water $(12 \%)$ and long distances to water sources $(7 \%)$.

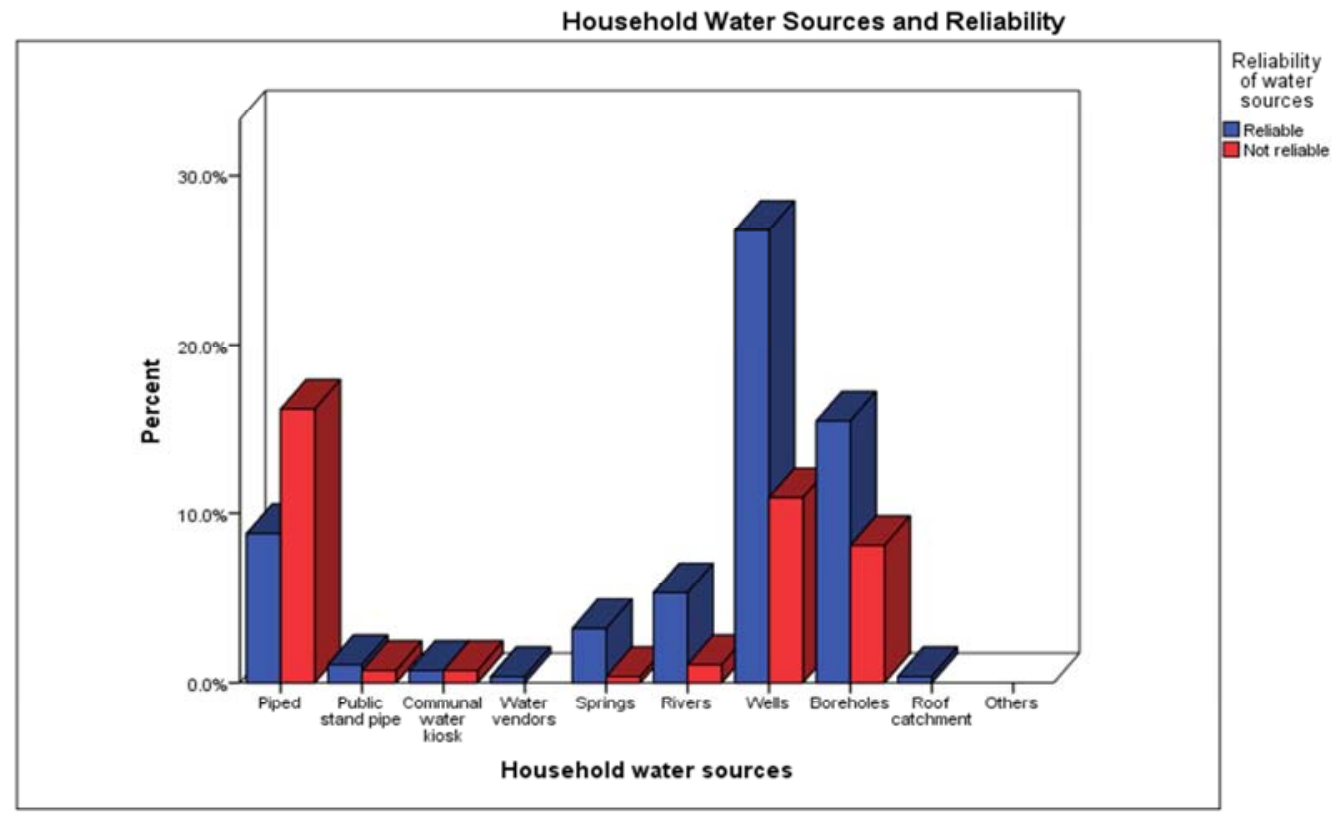

Figure 35. Source of household water. 


\section{Water Challenges in Nambale}

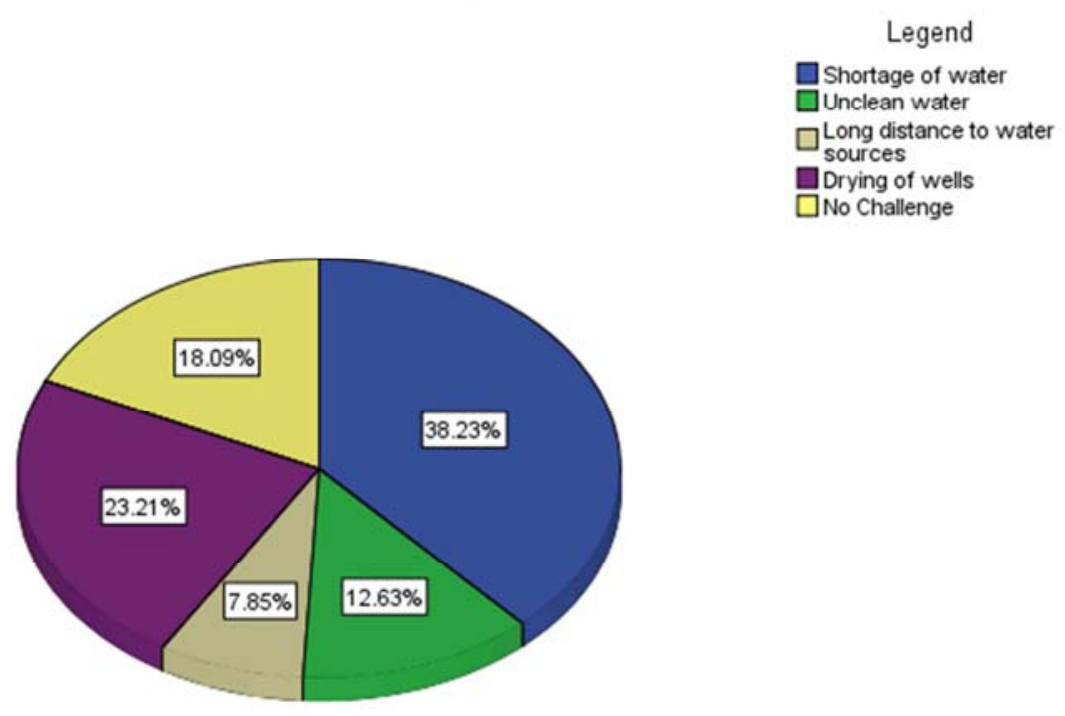

Figure 36. Water challenges in Nambale.

\subsubsection{Environment}

Environment is the surroundings of any living organism. Clean environment is essential for healthy living and for proper working. Taking care of the environment is the responsibility of every person in the society. Solid waste management data revealed that $36 \%$ of the residents prefer burning of waste followed by deposition in their own pit at $33 \%$. Other solid waste disposal mechanisms include composting (15\%), use of a waste disposal site (7\%), use of nearest open space at $6 \%$ and feeding to animals at $1 \%$. It was however found out that only $2 \%$ of the wastes was collected by County Government.

The challenges of solid waste management included poor waste disposal $(26 \%)$, lack of a waste disposal site $(19 \%)$, untimely collection of solid waste $(11 \%)$, lack of proper drainage $(8 \%)$, and flooding of pit latrines during heavy rains $(2 \%)$.

\section{Means of solid waste disposal}

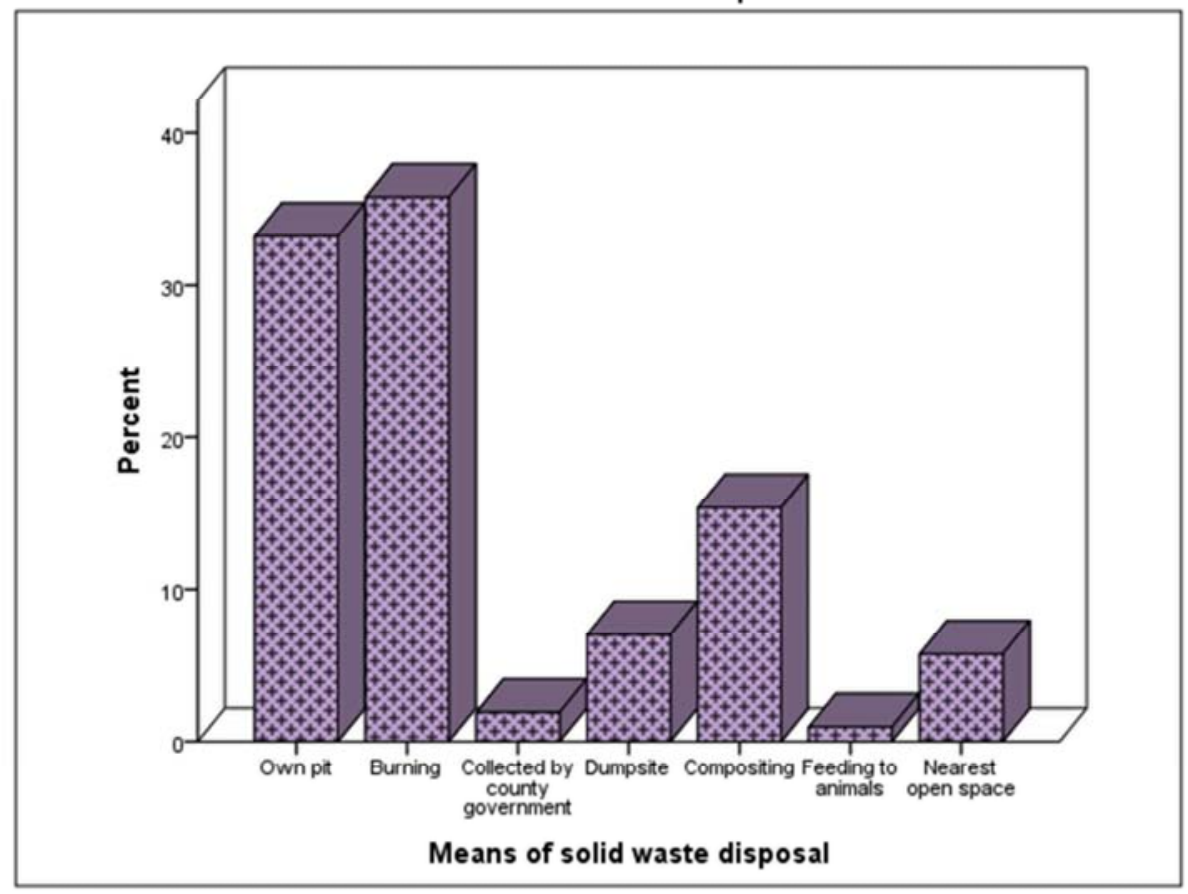

Figure 37. Means of solid waste disposal.

Liquid wastes also require a means through which they can be disposed of. The two major forms of liquid waste disposal were the use of pit latrines (96\%) and septic tanks at 4\%. It was however established that those who used their own pit 
latrines constituted $65 \%$ while those who shared pit latrines constituted $31 \%$. It is important to note that there is no conventional sewer system within Nambale town.

\section{Legend}

Poor waste disposal

$\square$ Waste

$\square$ Lack of a dumping site

Flooding of pit latrines during

heavy rains

$\square$ No proper drainage

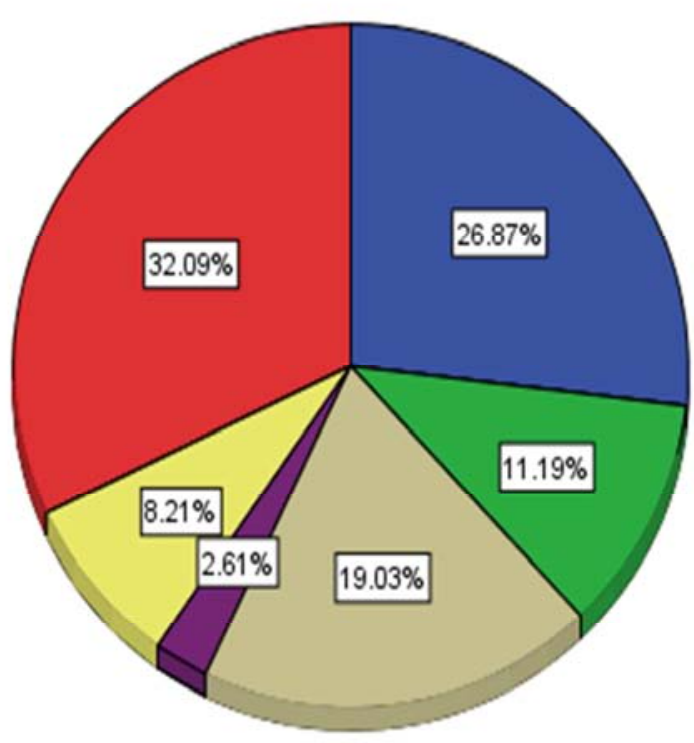

$\square$ No Challenge

Figure 38. Solid waste management challenges.

The environmental problems facing Nambale are shown in figure 39. Disease outbreak was a major environmental problem within the town at $20 \%$. Other problems included flooding at $17 \%$, fires at $7 \%$, lightening at $6 \%$ and whirlwind at $3 \% .48 \%$ of the respondents stated that there was no challenge in matters of environment. This can be associated to the forms of waste management such as burning the wastes that have problems that may be immediate or occur later. Waste disposal techniques were the problems facing the environment.

Means of human waste disposal

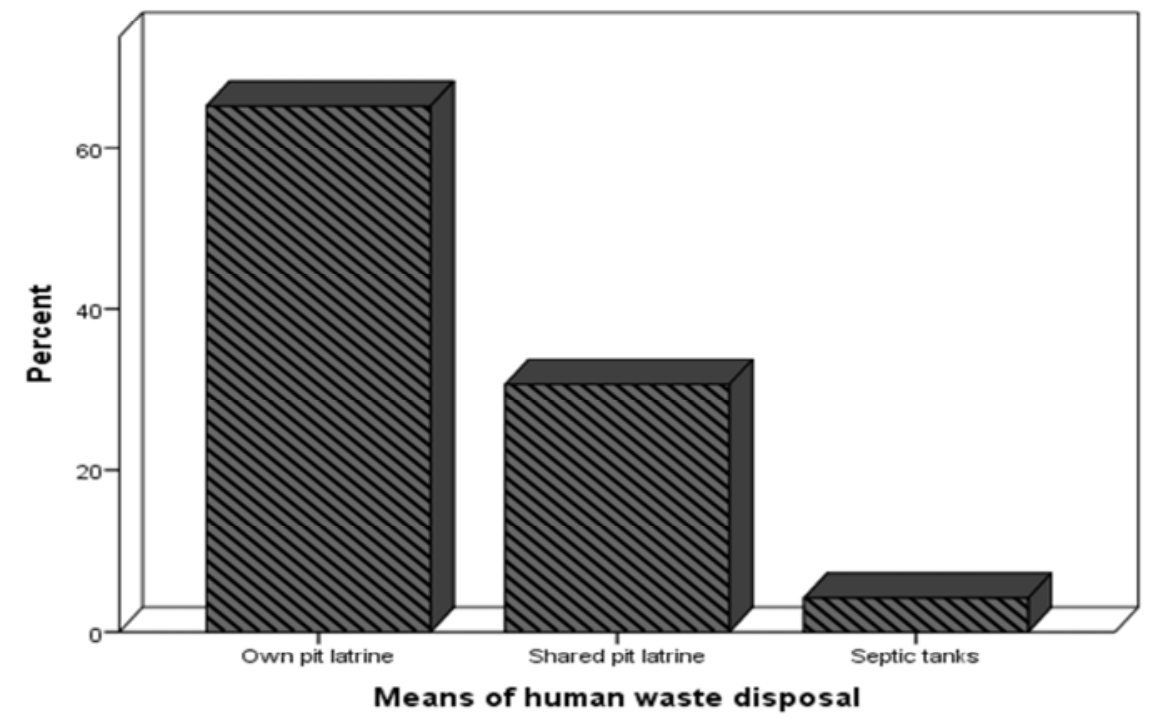

Figure 39. Human waste disposal. 


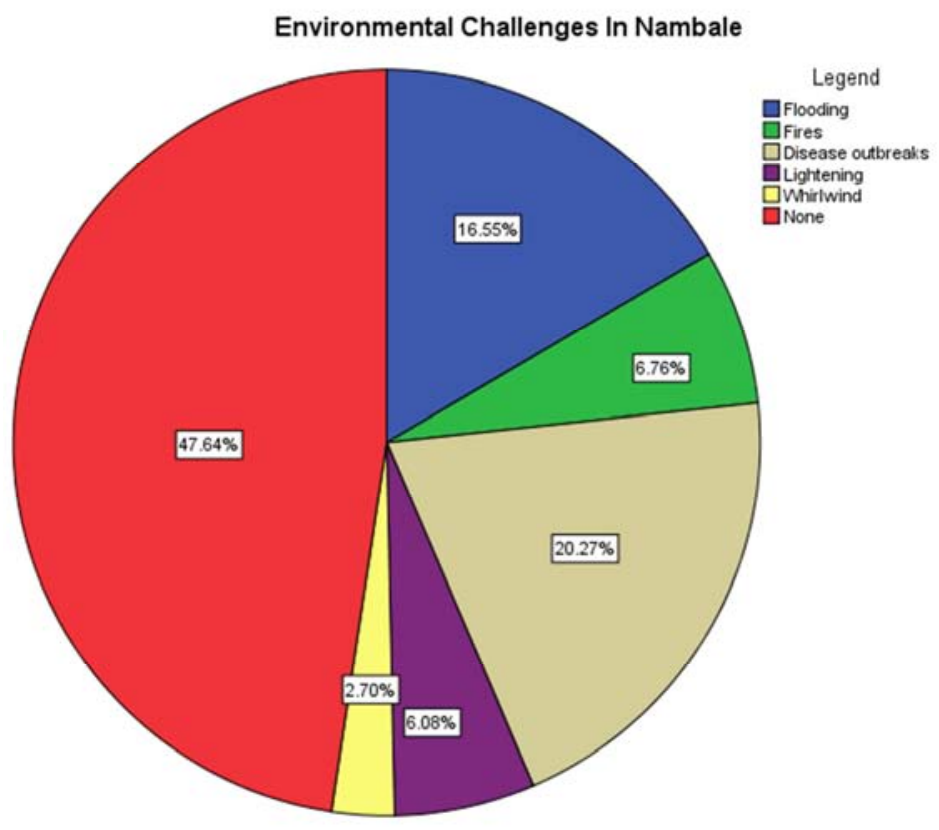

Figure 40. Environmental challenges in Nambale.

\subsection{SWOT Analysis}

SWOT Analysis is a simple but powerful tool for sizing up an organization's resource capabilities and deficiencies, its market opportunities, and the external threats to its future (Thompson et al. in [15]).

The acronym SWOT stands for 'strengths', 'weakness', 'opportunities' and 'threats'. SWOT Analysis is a tool used for strategic planning and strategic management in organizations. It can be used effectively to build organizational strategy and competitive strategy. In accordance with the System Approach, organizations are wholes that are in interaction with their environments and consist of various sub-systems. In this sense, an organization exists in two environments, one being in itself and the other being outside. It is a necessity to analyze these environments for strategic management practices. This process of examining the organization and its environment is termed SWOT Analysis [15]. In this context, an urban center is taken as an organizational establishment and SWOT Analysis is carried out relative to its location and other neighboring towns or features. Table 2 below depicts the analysis carried out for Nambale town.

Table 2. SWOT Analysis for Nambale town.

\begin{tabular}{|c|c|}
\hline \multicolumn{2}{|l|}{ RESIDENTIAL (HOUSING SECTOR) } \\
\hline Strength & Weakness \\
\hline $\begin{array}{l}\text { 1. Relatively flat and stable land free from earth tremors suitably for } \\
\text { construction of high-rise buildings } \\
\text { 2. Availability of construction material locally i.e. bush stones and bricks. } \\
\text { 3. Cheap labour from the highly unemployed population to work in the } \\
\text { construction industry } \\
\text { 4. Availability of roads that may ease accessibility to housing }\end{array}$ & $\begin{array}{l}\text { 1. Insufficient technology to allow construction of high-rise buildings and to } \\
\text { ensure safety for human occupation } \\
\text { 2. The cost of providing new housing units is relatively expensive for the } \\
\text { locals } \\
\text { 3. Inadequate/ lack of amenities such as sewerage, piped water and } \\
\text { electricity supply that go along with housing. } \\
\text { 4. Lack of designated residential zones }\end{array}$ \\
\hline Opportunities & Threats \\
\hline $\begin{array}{l}\text { 1. Opportunity for investment in the provision of new housing units. } \\
\text { 2. Opportunity for market of housing materials } \\
\text { 3. Opportunity for employment of the locals in the housing sector } \\
\text { INDUSTRIAL SECTOR }\end{array}$ & $\begin{array}{l}\text { 1. Construction of houses that unsafe for human occupancy } \\
\text { 2. Use of substandard material in the construction of houses that may } \\
\text { collapse causing catastrophes. }\end{array}$ \\
\hline Strength & Weakness \\
\hline $\begin{array}{l}\text { 1. Cheap labour from the highly unemployed population of the locals } \\
\text { 2. Local production of sugarcane for sugar industries } \\
\text { Opportunities }\end{array}$ & $\begin{array}{l}\text { 1. Unreliable power supply } \\
\text { 2. Inadequate skilled labour } \\
\text { Threats }\end{array}$ \\
\hline $\begin{array}{l}\text { 1. Opportunity for investment in industry } \\
\text { 2. Opportunity to revive the dormant sugar processing and milk industries } \\
\text { in the area } \\
\text { EDUCATION SECTOR }\end{array}$ & $\begin{array}{l}\text { 1. Competition from other industries } \\
\text { 2. Cheap products from Uganda due to close proximity to the border }\end{array}$ \\
\hline Strength & Weakness \\
\hline $\begin{array}{l}\text { 1. Free primary and secondary education } \\
\text { 2. CDF for development agenda in schools }\end{array}$ & $\begin{array}{l}\text { 1. Low staffing } \\
\text { 2. Poor school feeding programs }\end{array}$ \\
\hline
\end{tabular}




\begin{tabular}{ll}
\hline RESIDENTIAL (HOUSING SECTOR) & \\
\hline Opportunities & $\begin{array}{l}\text { 3. Inadequate land for expansion education facilities } \\
\text { Threats }\end{array}$ \\
\hline $\begin{array}{l}\text { Opportunity for employment } \\
\text { RECREATION SECTOR }\end{array}$ & Brain drain \\
\hline Strength & Weakness \\
\hline
\end{tabular}

1. Good climatic conditions favourable for outdoor recreation activities

2. Rich and diverse culture of Nambale residents vital in provision of a variety of recreation activities.

3. Peaceful nature of Nambale residents, a prerequisite for enjoyment recreation facilities

4. An almost natural environment serene for nature walk

1. The cost of setting up a recreation centre is relatively high

2. Prioritization of other land uses over recreation by the residents

3. Acquiring land for setting up a recreation centre may be a challenge

Opportunities

1. Opportunity to use riparian reserves along the major rivers (Walatsi, Nambale etc.) for recreation purposes.

2. Opportunity to utilise the culture of the locals in providing recreation activities

3. Opportunity to invest in recreation activities

ECONOMIC SECTOR

\section{Strength}

1. Strategic location near the Busia - Uganda border

2. Availability raw material from the neighbouring country for industries

3. Close proximity to transportation corridor (highway)

Opportunities

1. Good political environment that is favourable for economic growth.

2. High population offer market for local and imported good.

\section{Threats}

Competition from surrounding towns well endowed with recreation opportunities

\section{Weakness}

1. Inadequate market facilities

2. Lack of street light to enhance 24-hour economy

Threats

1. Cheaper goods from Uganda kill local businesses

2. Low income earning population with low purchasing capacity to enable sustainable internal business.

3. Falling sugar productions while sugar is the main economic activity in the region.

\section{WATER AND SANITATION}

\section{Strength}

1. The terrain of Nambale favour flow of water by gravity (gently sloping)

2. The presence of three rivers i.e. R. Suo, R. Walatsi and R. Nambale that provide water to the town

\section{Opportunities}

1. Strategic location to catchment areas

2. Availability of land for provision of sewer, dumpsite and cemetery

\section{ENERGY SECTOR}

\section{Strength}

Proximity to Uganda which supplies quit a large amount of power to Kenya.

\section{Opportunities}

Opportunity to exploit solar energy due to high insolation

\section{TRANSPORT SECTOR}

\section{Strength}

1. High connectivity of roads

2. Proximity to a cross-boundary road.

3. Gently sloping terrain that can support air transportation.

4. Gently sloping land hence easy construction of roads

5. Proper demarcation of road reserves by Kenya National Highways Authority (KeNHA)

\section{Opportunities}

1. Opportunity to convert earth roads to bitumen standards

2. Opportunity to open up previously inaccessible parts of the town

3. Opportunity to grow the matatu business and creation of more employment

\section{ENVIRONMENT SECTOR}

\section{Strength}

1. Natural Environment - vast coverage of indigenous trees

2. Presence of environmental institutions (NEMA)

3. There is presence of waterfowl habitat (R. Suo,)

\section{Opportunities}

1. Opportunity for tourism (bird watching and wetlands)

2. Opportunity for investment

\section{Weakness}

Inadequate provision of potable water

\section{Threats}

1. Vulnerability to water borne diseases

2. Pit latrines pose a threat to ground water

\section{Weakness}

1. Frequent power black outs.

2. Lack of diverse sources of energy

\section{Threats}

Destruction of electricity distribution lines during road construction

\section{Weakness}

1. Reliance on previous existing plans

2. Poor implementation of the current development plan

3. There is no road signage and bumps

4. Intermodal conflict along the major Mumias Busia road i.e. motorcycles, pedestrians and vehicle

5. Narrow and poor roads condition

Threats

Encroachment on road reserves

\section{Weakness}

1. Weak environmental institutions

2. Low prioritization in environmental concern

3. Low funding

4. Poor enforcement of environmental policies

Threats

1. Climate change

2. Population bomb

3. Resource use conflict

4. Invasive species 


\begin{tabular}{|c|c|}
\hline \multicolumn{2}{|l|}{ RESIDENTIAL (HOUSING SECTOR) } \\
\hline & 5. Kisoko gets its domestic water from protected area \\
\hline \multicolumn{2}{|l|}{ AGRICULTURAL SECTOR } \\
\hline Strength & Weakness \\
\hline \multirow{2}{*}{$\begin{array}{l}\text { 1. Subsidized agricultural inputs from the government } \\
\text { 2. High populations offer market for agricultural products. } \\
\text { Opportunities }\end{array}$} & Overreliance on mono-cropping and rain fed agriculture \\
\hline & Threats \\
\hline $\begin{array}{l}\text { 1. Adjacency to rivers which can promote irrigation farming } \\
\text { 2. Ready market for agricultural produce }\end{array}$ & $\begin{array}{l}\text { 1. Land fragmentation into unsustainable portions } \\
\text { 2. Mechanized agriculture leading to soil erosion, air pollution } \\
\text { 3. GMOs } \\
\text { 4. Climate change and global warming } \\
\text { 5. Cheap agricultural produce from Uganda }\end{array}$ \\
\hline \multicolumn{2}{|l|}{ HEALTH SECTOR } \\
\hline Strength & Weakness \\
\hline $\begin{array}{l}\text { 1. Funding from both national and county government } \\
\text { 2. Adoption of beyond zero campaign (reduce child mortality) } \\
\text { 3. Provision of NHIF services to the locals } \\
\text { 4. Campaigns for vaccination of chronic diseases }\end{array}$ & $\begin{array}{l}\text { 1. Poor health facilities } \\
\text { 2. Low human health personnel } \\
\text { 3. Inadequate land for expansion of health facilities } \\
\text { 4. Inadequate funding } \\
\text { 5. Level hospitals offer only outpatient services }\end{array}$ \\
\hline Opportunities & Threats \\
\hline 1. Opportunity for employment & 1. Global warming leading to invasive diseases \\
\hline 2. Donor funding (USAID) & 2. Unregulated movement of people from Uganda to Kenya (Ebola) \\
\hline
\end{tabular}

\section{Conclusion}

Like majority of urban areas in Kenya, Nambale faces a lot of development challenges that include but not limited to linear settlement pattern where development are mainly concentrated along the main roads hence limiting access and even distribution of developments, unplanned urban settlements, high poverty levels, lack of street lights, inadequate access to energy, low levels of access and enrolment in education facilities and high levels of school drop-outs, low levels of access to health facilities and high patient to doctor ratio, lack of proper market systems and facilities, inadequate access to quality water and sanitation, lack of disaster management plan and kitty, lack of designated dumpsites and proper waste management plan, poor/inadequate transport and communication network, food insecurity, lack of integrated development approach and high rates of insecurity. The presence of such challenges in Nambale compromises the right of its residents to live in a sustainable, safe, inclusive and a resilient urban area. Consequently, there is an urgent need to plan the town so as to promote optimal realization of its social, economic and environmental potentials.

\section{Acknowledgements}

We express our gratitude to Dr. A. Kiplagat and Dr. J. Ngetich for the invaluable support and guidance extended to us throughout the research period. They are Lecturers in the Department of Environmental Monitoring, Planning and Management at the University of Eldoret. Our gratitude also goes to the management of University of Eldoret for granting us financial and technical support to carry out the field study through the School of Environmental Studies, Department of Environmental Monitoring, Planning and Management.

Special thanks to laboratory technician Mr. Samson
Odhiambo and Driver Mr. Sammy for efforts in facilitating the field survey. Last but not least we wish to pass our gratitude to the County Government of Busia, Nambale Subcounty administration for giving us a go ahead to carry out the field study and providing the required data. Finally, our appreciation goes to all the students both postgraduate and third year undergraduate 2018/2019 academic year for the teamwork exemplified throughout the study.

\section{References}

[1] United Nations. (2016). Urbanization and Development: Emerging Futures. Retrieved from https://unhabitat.org/wpcontent/uploads/2014/03/WCR-\%20Full-Report-2016.pdf

[2] Mondal, P. (1999). Major Factors that Encourage Urbanization. Retrieved from http://www.yourarticlelibrary.com/urbanisation/3-majorfactors-that-encourage-urbanization/9991

[3] Scott, J. (2015). The risks of rapid urbanization in developing countries. Retrieved from https://www.zurich.com/en/knowledge/articles/2015/01/therisks-of-rapid-urbanization-in-developing-countries

[4] Brankica, M. (2018). Integrated Urban Planning in Theory and Practice. Retrieved from

https://www.researchgate.net/publication/325714737_INTEG RATED_URBAN_PLANNING_IN_THEORY_AND_PRAC TICE

[5] Government of Kenya. (2011). Urban Areas and Cities Act No. 13 of 2011. Revised Edition 2016 [2012]. Retrieved from http://kenyalaw.org/lex/rest//db/kenyalex/Kenya/Legislation/E nglish/Acts\%20and\%20Regulations/U/Urban\%20Areas\%20a nd\%20Cities\%20Act\%20Cap.\%20275\%20-

$\% 20$ No.\%2013\%20of\%202011/docs/UrbanAreasAndCitiesAc t13of2011.pdf

[6] Government of Kenya. (1996). Physical Planning Act Cap 286. Revised edition 2012 [2010]. Retrieved from http://extwprlegs1.fao.org/docs/pdf/ken101236.pdf 
[7] Government of Kenya. (2012). County Government Act, 2012. Retrieved from

http://extwprlegs1.fao.org/docs/pdf/ken115452.pdf

[8] Omid, M. (2014). Strategic Planning and Urban Development by Using SWOT Analysis. The case of Urmia City. Romania Review of Regional Studies, 4(2), 47-54. Retrieved from http://rrrs.reviste.ubbcluj.ro/arhive/Artpdf/v10n22014/RRRS1 0220145.pdf

[9] County Government of Busia. (2018). County Integrated Development Plan 2018-2022. Retrieved from https://www.busiacounty.go.ke/wpcontent/uploads/2018/05/FINAL-DRAFT-BUSIA-COUNTYCIDP-2018-2022.pdf

[10] Manly, B.F.J. and Alberto, J.A.M. (2015). Introduction to Ecological Sampling. CRC Press. Retrieved from https://www.researchgate.net/publication/278658316_Line_Tr ansect_Sampling
[11] Government of Kenya. (2010). Constitution of Kenya 2010. Retrieved from http://extwprlegs1.fao.org/docs/pdf/ken127322.pdf

[12] Daily Nation. (2018). Uhuru Kenyatta Outlines 'Big Four Progress' [Press release]. Retrieved from https://www.nation.co.ke/news/Uhuru-Kenyatta-outlines-bigfour/1056-4893040-14u1vl6/index.html

[13] United Nations. (2015). Sustainable Development Goals. Retrieved from https://www.undp.org/content/dam/undp/library/corporate/bro chure/SDGs_Booklet_Web_En.pdf

[14] Rural Electrification Authority (https://www.rea.co.ke/)

[15] Gurel, E. and Tat, M. (2017). SWOT Analysis: A Theoretical Review. The Journal of International Social Research, 10(51), 994-1006. Retrieved from https://www.researchgate.net/publication/319367788_SWOT_ ANALYSIS_A_THEORETICAL_REVIEW 